\title{
Mosaic Recombinant Adeno-associated Virus Vector rAAV/DJ/CAG for Targeted Gene Delivery to Melanoma Cells Metastasized to the Lung
}

\author{
MILENA CZAJKA ${ }^{1}$, AGNIESZKA ZAJKOWSKA ${ }^{1}$, MACIEJ GAWLAK ${ }^{2}$, \\ MAGDALENA BUJALSKA-ZADROZNY ${ }^{2}$ and MACIEJ MALECKI ${ }^{1}$ \\ ${ }^{1}$ Department of Applied Pharmacy, Faculty of Pharmacy, Medical University of Warsaw, Warsaw, Poland; \\ ${ }^{2}$ Department of Pharmacodynamics, Centre for Preclinical Research and Technology, \\ Medical University of Warsaw, Warsaw, Poland
}

\begin{abstract}
Background/Aim: Patients with metastasized melanoma have limited treatment options and poor diagnosis. Therefore, the development of treatments requires a new therapeutic approach, of which gene therapy using $r A A V$ vectors can be proposed. The aim of the study was to examine the efficiency of the $r A A V$ vector to transduce mouse melanoma cells both in vitro and in vivo. Materials and Methods: Different rAAV serotypes encoding GFP under the control of both chicken beta-actin and cytomegalovirus promoters were used in the experiments. Intranasal, intraperitoneal, intravenous and intratumoral pathways of administration of $r A A V$ vectors were tested using quantitativePCR and immunohistochemical staining. Results: The highest transduction efficiency in metastatic cells in vivo was observed 7 days after intranasal administration of a $10^{10} \mathrm{gc} / 0.03 \mathrm{ml}$ dose of rAAV/DJ-CAG. Conclusion: Melanoma gene therapy based on rAAV vectors is a possible treatment option.
\end{abstract}

Melanoma is a tumor that derives from pigment cells melanocytes, which develop from the neural tissue of integuments. The most common starting point of melanoma is the skin, but it may also be formed within the mucous membranes of the gastrointestinal tract or in the eyeball. It is a cancer with a high potential for metastasis $(1,2)$. Despite the progress in anti-cancer treatment, the number of deaths due to

This article is freely accessible online.

Correspondence to: Milena Czajka, Department of Applied Pharmacy, Faculty of Pharmacy, Medical University of Warsaw, Banacha 1A Street, 02-097 Warsaw, Poland. Tel: +48 535143512, e-mail: milena.czajka@wum.edu.pl

Key Words: Melanoma, metastatic melanoma, rAAV, intranasal delivery, lungs. metastatic melanoma is still increasing and from the beginning of 2019 circa 7,000 patients in the USA died of it (1). Its aggressiveness causes as much as $90 \%$ of deaths among all skin cancers (3). The median survival of patients with melanoma who have distant metastases is shorter than 1 year (4). In the initial stage, the disease is curable, but unfortunately in the advanced stage, when metastasis occurs, it is practically incurable (5). The treatment, which has so far been proposed for the advanced stage, does not provide the desired benefit and the survival of these patients remains unsatisfactory. For instance, the annual survival rate after treatment with targeted therapy for the dual $B R A F / M E K$ mutation is only about $50-60 \%$ $(4,6)$. Therefore, one of the future therapeutic approaches in the treatment of metastatic melanoma can be gene therapy using rAAV vectors, especially with the use of hybrid serotypes, which can achieve high efficiency of gene delivery (7-9).

AAV viruses are non-pathogenic, small (approx. $25 \mathrm{~nm}$ in diameter) and infect both dividing and non-dividing cells. A distinguishing trait of rAAV is also the occurrence of various serotypes, which are characterized by strong tropism to selected cell types, making them ideal candidates for gene therapy (10). rAAV viruses have become increasingly popular in clinical trials $(11,12)$. In recent years, two pharmaceutical products using rAAV vectors - Glybera (13) and Luxturna (14) have been registered. Recent studies conducted on hybrid/mosaic serotypes have shown a greater transduction efficiency and are more heterogeneous, both in cellular and tissue specificity (15). The new rAAV vectors are created by a number of innovative techniques, including site-directed mutagenesis, Cry-Em and a recent novum - the CRISPR method (16). With the CRISPR method it is possible to edit a genome (17), modulate gene expression (16-18) or to distinguish different nucleic acids of various Zika viruses (19). CRISPR is an innovative method that can be used for breakthrough discoveries and can serve as a tool for imaging live cells. First of all, its application is intended for the 
treatment of cancer $(20,21)$, cardiological diseases $(22,23)$, haematologic diseases (24), muscular dystrophy (25-27), and therapy at the level of human embryos, where it can be used to repair mutations $(28,29)$. Moreover, this method is also applied to improve the delivery of genes to cells with the use of rAAV vectors, which are an interesting group of carriers used in gene therapy (30-32). Genetic modifications of viral vectors using e.g. the CRISPR method, are intended to increase and improve the efficiency of the rAAV vector transduction. These methods, by manipulating the capsid surface, make it possible to avoid Nab neutralising antibodies, so that genes can be delivered more efficiently to cells (10).

Hybrid serotypes are known to be one of the strategies for improving gene delivery to cells (33). Grimm et al. have published a rAAV/DJ construct that seems to be a carrier with an increased ability for cancer cell transduction. rAAV/DJ is a serotype formed by the intersection of eight different wild AAV serotypes by combining the capsids of these vectors (34). Thanks to these modifications, the $\mathrm{rAAV} / \mathrm{DJ}$ vector exhibits a wider range of tropism and better transduction efficiency. In addition, it is less immunogenic compared to other rAAV vectors, because it has the ability to avoid neutralising antibodies (34-36). Therefore, the rAAV/DJ vector is a promising carrier that can be used for the treatment of cancers $e . g$. in cancers that metastasize to the lungs, including melanoma $(7,37,38)$.

In modern times, non-invasive systems for gene delivery are sought (39-41). A promising route of administration has been suggested to be intranasal administration, where in recent years, has been shown to be a biopharmaceutically privileged, readily accessible and susceptible area when it comes to the administration of medications and, importantly, construct vectors based on adenoviruses and adeno-associated viruses, but also on others, e.g. herpes virus and lentivirus (42). The intranasal route has been used in many studies as a favorable route of administration (43-45), and is particularly beneficial in providing medication to the bronchus (46-50). Zahoor et al., Justo et al. and others have suggested that lung diseases can be treated by inhalation (51-55). Santry et al. have shown that the intranasal route can serve to supply $\mathrm{rAAV}$ vectors directly to the lungs (40). The intranasal route can also be used to deliver medicines to other organs. For example, the beneficial use of this route of administration is inter alia: administration of insulin in the treatment of Alzheimer's disease (56-58), eye medications including erythropoietin, which saves photoreceptors in the degenerative retina (59), migraine treatment (60), epilepsy (61) and depressive diseases (62). The intranasal route of administration allows us to achieve both local and systemic effects (63). Therefore, intranasal administration is considered an alternative non-invasive route of administration of medications, including gene preparations, which can produce a therapeutic effect with very high efficacy (64).

In our experiments, we used rAAV vector serotypes rAAV2/1-rAAV2/9 and rAAV/DJ. The tests were conducted with the rAAV under the control of both the cytomegalovirus (CMV) and the CMV early enhancer element, and chicken beta-actin (CAG) promoters encoding a GFP reporter gene.

The purpose of this study is directly linked to the determination of the suitability of molecular marking B16-F10 cells with the use of rAAV vectors both in vitro and in vivo. The efficacy of mouse melanoma cell transduction was evaluated with the use of a fluorescence microscopy, qPCR, Countess II FL Automated Cell Counter, immunohistochemical staining and ELISA. Our research showed the usefulness of rAAV vectors for the delivery of reporter genes into mouse metastasized cells, through the intranasal, intraperitoneal, intravenous, and intratumoral routes of administration. The highest infection efficiency was observed after intranasal administration of the rAAV vector, the rAAV/DJ serotype. These discoveries underline the efficient administration of selected rAAV vectors to melanoma cells.

\section{Materials and Methods}

rAAV vectors. Recombinant AAV vectors were purchased from VECTOR BIOLABS (Malvern, PA USA). We used serotypes rAAV1rAAV6, rAAV8-rAAV9 and rAAV/DJ vectors. This rAAV serotype virus expresses eGFP (enhanced Green Fluorescent Protein) under the control of the CMV or a hybrid of the CMV early enhancer element and chicken beta-actin promoter (CAG). Titer of the original stocks: $1 \times 10^{13} \mathrm{gc} / \mathrm{ml}$.

Cell lines. Two cell lines were used: the mouse melanoma line: B16F10 (ATCC ${ }^{\circledR}$ CRL- $6475^{\mathrm{TM}}$, Manassas, VA, USA) and the mouse fibroblast cell line: NIH/3T3 (ATCC ${ }^{\circledR}$ CRL-1658 ${ }^{\mathrm{TM}}$ ) used as a control. The cell lines were maintained in the Dulbecco's Modified Eagle Medium (Gibco ${ }^{\circledR}$ BRL, Life Technologies ${ }^{\mathrm{TM}}$, Waltham, MA USA) supplemented with $10 \%$ fetal bovine serum (Lonza, Biowhittaker, Walkersville, MD, USA) and the antibiotic/antimycotic solution (AAS) $\left(\mathrm{Gibco}^{\circledR}\right.$ Life Technologies $\left.{ }^{\mathrm{TM}}\right)$. The cells were maintained under standard conditions $\left(\right.$ at $37^{\circ} \mathrm{C}$ and in a humidified $5 \% \mathrm{CO}_{2}$ atmosphere).

Cell transduction procedure. B16-F10 and NIH/3T3 cells were seeded on $6 \mathrm{~cm}$ diameter dishes at the density of $5 \times 10^{4}$ and $1 \times 10^{5}$, respectively. After $24 \mathrm{~h}$, complete media (DMEM with 10\% FBS) were changed to DMEM with $2 \%$ FBS. rAAV vectors were moved from $-80^{\circ} \mathrm{C}$ to room temperature, and underwent a gentle vortex and a short spin. Then, they were added to cells with a multiplicity of infection (MOI) of 40,000. The DMEM was replaced every $48 \mathrm{~h}$. Seven days later, the efficiency of cell transduction was evaluated using several methods.

\section{Evaluation of the cell transduction efficiency.}

Microscopic image analysis. Imaging of the cells after transduction was performed using the inverted fluorescent microscope Olympus IX53, with the $10 \times$ objective in both the Brightfield (BF) and fluorescent light (FITC). Editing of images was performed with an Olympus cellSens2010 software.

Countness $^{T M}$ II Automated Cell Counter (ThermoFisher). Media were removed, cells were rinsed with PBS and trypsinized (Trypsin-EDTA 
A

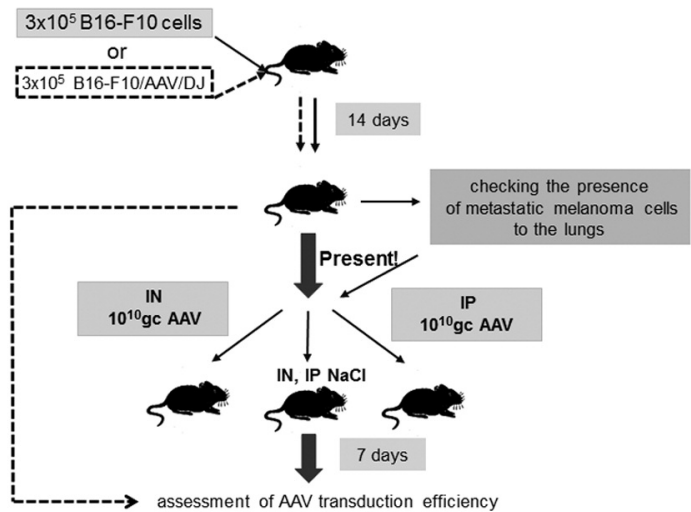

B

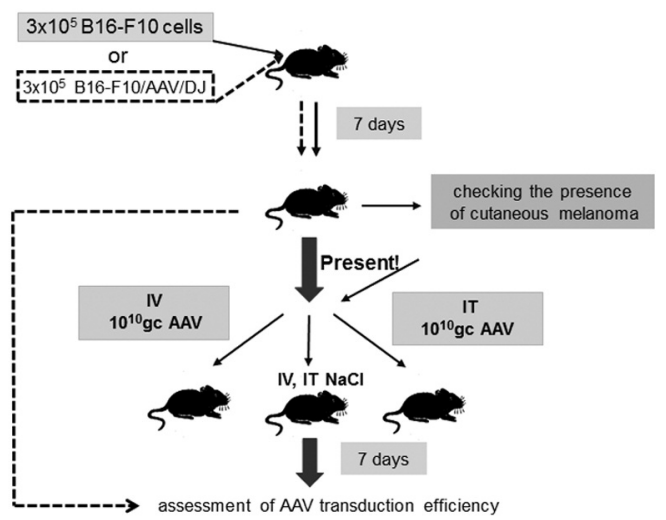

Figure 1. Diagram showing the administration of $r A A V$ vectors to B16-F10 melanoma tumor-bearing C57BL/6J mice. A: melanoma model with lung metastasis that used intranasal (IN) and intraperitoneal (IP) administration of rAAV vectors, B: melanoma skin model that used intravenous (IV) and intratumoral (IT) administration of rAAV vectors.

Solution 1×, Sigma-Aldrich ${ }^{\circledR}$, Saint Louis, MO, USA). After 4 min of incubation at $37^{\circ} \mathrm{C}$, the cells were harvested and $4 \mathrm{ml}$ of DMEM was added. Ten $\mu$ l of the suspension was then applied to the cell counting slide (EVE ${ }^{\mathrm{TM}}$ Cell Counting Slides, NanoEnTek), the appropriate profile was selected (with the use EVOS LED Light Cube GFP: ALexaFluor488) and the cells showing GFP expression were counted.

Enzyme-linked immunosorbent assay. After transduction, total protein was isolated using the RIPA buffer composition (Tris $\mathrm{Cl}$ pH 7.510 $\mathrm{mM}, \mathrm{NaCl} 150 \mathrm{mM}, \mathrm{NP} 401 \%$, sodium deoxycholate $0.5 \%$, SDS $0.1 \%$, water), containing a protease inhibitor cocktail (SigmaAldrich $\left.{ }^{\circledR}\right)$. For the determination of GFP protein concentration in cells after transduction, an enzymatic immunoassay (GFP ELISA Kit, AKR-121, CELL BIOLABS, INC., San Diego, CA, USA) was used. Total protein was diluted $1: 100$ and then GFP was determined according to the manufacturer's protocol. The standard curve was prepared using the dilution series of recombinant GFP standard, in the concentration range of $0 \mathrm{ng} / \mathrm{ml}$ to $2 \mathrm{ng} / \mathrm{ml}$ in Assay Diluent, included in the GFP ELISA kit.

$q P C R$. After transduction of the rAAV vectors, total DNA from B16F10 and NIH/3T3 cells was isolated according to the manufacturer's protocol, in the High Pure Viral Nucleic Acid Kit (Roche Life Science). qPCR was performed on the StepOnePlus Real Time PCR System (Applied Biosystems ${ }^{\circledR}$ ) using the Taqman ${ }^{\circledR}$ Universal Master Mix II, with UNG (Applied Biosystems ${ }^{\circledR}$ ), and probe/primer sets were designed to recognize the ITR sequence. Reverse: 5'CGGCCTCA GTGAGCGA3', Forward 5'GGAACCCCTAGTGAT GGAGTT3' and probe 6-FAM-CACTCCCTCTCTGCGCGC-TAMRA (65). A dilution series of the calibration curve using pAAV-IRES-hrGFP (Agilent Technologies, Santa Clara, CA, USA) was used to quantitatively evaluate the copy number of the ITR sequence present in tissues and cells. The standard curve included a range between 10 and 1010 molecules. All samples were analysed in triplicate using $50 \mathrm{ng}$ total DNA/sample.

Gene expression. Total RNA from B16-F10 and NIH/3T3 cells was isolated using TRI Reagent Solution ${ }^{\mathrm{TM}}$ (Invitrogen $^{\mathrm{TM}}$ ). Reverse transcription was performed using the High Capacity RNA-to-cDNA kit (Applied Biosystems ${ }^{\mathrm{TM}}$ ) according to the manufacturer's instructions. Gene expression was investigated with TaqMan ${ }^{\circledR}$ Array 96-WELL FAST Plates (Applied Biosystems ${ }^{\mathrm{TM}}$ ): mouse lipid regulated genes (cat no: 4415461) and mouse $\mathrm{ABC}$ transporters (cat no: 4418752). All samples were analysed in duplicate using $100 \mathrm{ng}$ total RNA/sample. The relative gene expression was calculated using the $\Delta \Delta \mathrm{Cq}$ method. The results were analyzed using the ExpressionSuite Software v 1.1.

In vivo gene transfer experiments

Animals, B16-F10 cells, rAAV vectors. C57BL/6J mice of both sexes, aged approximately 8-10 weeks, obtained from the Mossakowski Medical Research Centre, Polish Academy of Sciences, were used. The animals were bred at a temperature of about $21^{\circ} \mathrm{C}$, with free access to food and water, and on a $12 \mathrm{~h} / 12 \mathrm{~h}$ day/night cycle, in the animal laboratory of Center for Preclinical Research and Technology, Medical University of Warsaw. The experiments were performed after obtaining the approval of the WUM Ethical Committee (consent no. 60/2013). The scheme of the experiment is shown in Figure 1.

In our studies, a metastatic and a localized mouse melanoma model were used (Figure 1). The B16-F10 cells were maintained in standard conditions, supplemented with $10 \%$ FBS. Cells were introduced to $\mathrm{C} 57 \mathrm{BL} / 6 \mathrm{~J}$ laboratory mice. Melanoma cells at the density of $3 \times 10^{5} / 0.1 \mathrm{ml} \mathrm{PBS} /$ mouse were administered intravenously (Figure 1A) or subcutaneously (Figure 1B). The selected mice also received B16-F10 cells, which were previously subjected to rAAV in vitro transduction (Figure 1). Seven days after administration of melanoma cells, the mice were checked for the presence of dermal melanoma (Figure 1B), while after 14 days they were checked for lung metastasis (Figure 1A). The presence or not of tumors determined the further experiments. rAAV vectors were transduced to the animals. Based on the in vitro studies, $\mathrm{rAAV}$ vectors with the highest efficiency of transduction in mouse melanoma cells were selected. For this purpose, $0.03 \mathrm{ml}$ and $0.1 \mathrm{ml}$ of vector formulations were made containing rAAV vectors of the titer $10^{10}$ copies (Figure $1 \mathrm{~A}$ and $\mathrm{B})$. The control animals were administered $0.03 \mathrm{ml}$ and 0.1 $\mathrm{ml}$ of $0.9 \%$ sodium chloride solution.

Preparation for intranasal administration: A gene formulation containing $10^{10} \mathrm{gc}$ of the rAAV vector at the total volume of $0.03 \mathrm{ml}$ 
was administered directly into the nasal cavity, by dropping it into the nostrils using pipettes and sterile tips. Mice spontaneously and passively inhaled the gene formulation administered to them (Figure 2). Seven days after the administration, the animals were sacrificed in order to collect pulmonary tissue and other organs, to estimate the biodistribution of rAAV vectors after using the intranasal route of administration.

Preparation for intraperitoneal administration: Properly prepared $10^{10} \mathrm{gc}$ of rAAV vectors at the total volume of $0.1 \mathrm{ml}$ were given directly into the peritoneal cavity (Figure 1A). Seven days after the administration, the animals were sacrificed to collect pulmonary tissue and other organs to estimate the biodistribution of rAAV vectors via the intraperitoneal route of administration.

Preparation for intravenous administration: $10^{10} \mathrm{gc}$ of rAAV vectors at the total volume of $0.1 \mathrm{ml}$ were administered directly to the caudal vein of the laboratory mice (Figure 1B). Seven days after the administration, the animals were sacrificed to collect cutaneous tumors and other organs, to estimate the biodistribution of rAAV vectors via the intravenous route of administration.

Preparation for intratumoral administration: A total of $10^{10} \mathrm{gc}$ of rAAV at the total volume of $0.1 \mathrm{ml}$ was administered directly to the tumor (Figure 1B). Seven days after administration, animals were sacrificed in order to collect cutaneous tumors and other organs, to estimate the biodistribution of rAAV vectors via the intratumoral route of administration.

Transduction of B16-F10 cells with rAAV/DJ-CAG: Melanoma cells were prepared according to the cell transduction procedure protocol (see Materials and Methods). The efficiency of the transduction was analysed 7 days after rAAV transduction, to determine whether at least $80 \%$ of GFP positive cells were administered to the laboratory mice at the density of $3 \times 10^{5} /$ mouse. The transductants developed in this way were then administered subcutaneously or intravenously to produce metastatic melanoma in the lungs. After 7 days, in the case of intradermal administration and after 14 days in the metastatic model, tissues were collected to estimate the transduction efficiency (Figure 1).

Immunohistochemistry. Immunofluorescence analysis was used to assess the efficiency of transduction in B16-F10 cells. The study used C57BL/6J laboratory mice with melanoma and lung metastases, which were administered rAAV gene formulations via the intranasal or intraperitoneal route (Figure 1A). Seven days after administration of rAAV vectors, the animals were perfused with PBS (100 $\mathrm{ml}$ of PBS per $100 \mathrm{~g}$ of body weight) and $4 \%$ paraformaldehyde (PFA, 100 $\mathrm{ml}$ per $100 \mathrm{~g}$ of body weight). Then, organs were dissected and transferred to $4-8^{\circ} \mathrm{C}$ overnight. Next, tissues were immersed at $4-8^{\circ} \mathrm{C}$ in $30 \%$ sucrose three times for about $72 \mathrm{~h}$. After that, organs were frozen in dry-ice-cold heptane, cut in a cryostat (Leica CM1950) into 15 slices and mounted on slides (ThermoScientific, SUPERFLOST ${ }^{\circledR}$ PLUS). For immunohistochemical staining, slices were incubated in normal donkey serum (Abcam, ab7475) in PBS containing 0.3\% Triton X-100, for $1 \mathrm{~h}$ at room temperature (RT), in a humid chamber. Next, the primary antibodies were added: anti-GFP (Abcam, ab5450; 1:500) and anti-melanoma (Abcam, ab137078; 1:500) for $1 \mathrm{~h}$ at RT and then transferred to a refrigerator for $24 \mathrm{~h}$. After $24 \mathrm{~h}$, the slices were rinsed with PBS containing Triton X-100 (Sigma-Aldrich ${ }^{\circledR}$ ), and then incubated with secondary donkey anti-rabbit antibody (Abcam, ab150075; 1:500) and donkey anti-goat antibody (Abcam, ab175704) at RT for $1.5 \mathrm{~h}$. After washing with PBS containing Triton X-100

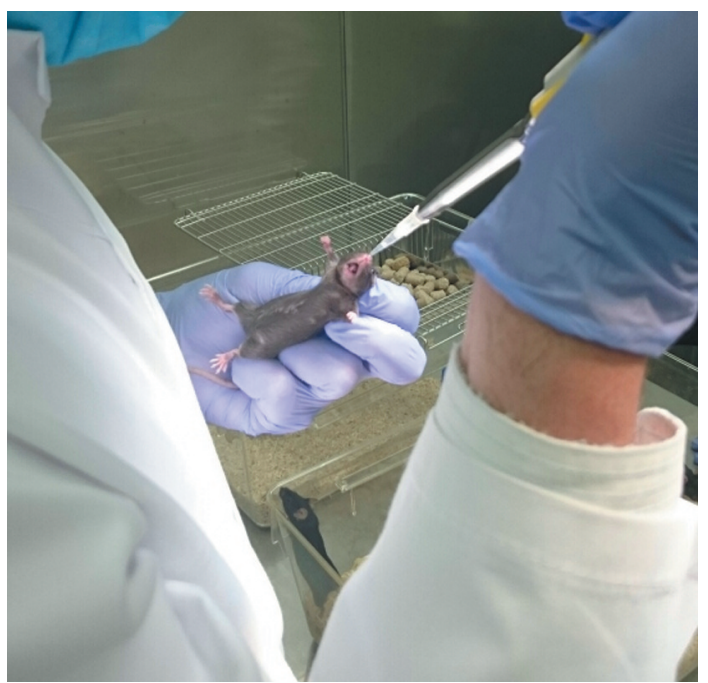

Figure 2. Intranasal administration of the $r A A V$ gene formulation to laboratory mice of the C57BL/6J strain.

slices were coversliped. Images were collected using the confocal laser scanning microscope Olympus FV1000 and analysed with Fiji/ImageJ (66).

$q P C R$. Total DNA from animal tissues, collected after administration of the rAAV vectors, was isolated using the genomic Maxi or Midi kit (depending on the weight of material used) (A\&A Biotechnology, Gdynia, Poland). qPCR was performed as described above (see Evaluation of the cell transduction efficiency; qPCR).

Statistical analysis. All results are shown as mean \pm standard deviation. Each experiment was conducted at least three times. The results are presented at the significance level: $* p<0.05, * * p<0.01$ and $* * * p<0.001$. In all cases, one-way variety ANOVA test was used. The Statistica 13.1 software was used.

\section{Results}

Transduction efficiency of $r A A V$ vectors to melanoma and fibroblast cells in vitro. B16-F10 melanoma cells and mice $\mathrm{NIH} / 3 \mathrm{~T} 3$ fibroblast control cells were transduced using ten different serotypes of adeno-associated viruses. rAAV vectors were used in three different MOI=200, 20,000 (both data not shown) and 40,000. rAAV demonstrated the GFP protein expression. Serotypes rAAV2/2 and rAAV/DJ were given in variants containing two different promoters in order to check whether a particular promoter affects the efficiency of GFP expression. The transduction efficiency was measured 7 days after the administration of rAAV vectors using several methods: a fluorescence microscope with the use of which the preparations were viewed at $10 \times$ magnification in bright light and fluorescent light, with excitation and emission spectrum peak wavelengths of approximately $495 \mathrm{~nm} / 519 \mathrm{~nm}$ (Figure $3 \mathrm{~A}$ and $\mathrm{B})$. This allows a visual estimation of the cells that 
demonstrates the protein expression of green fluorescence. The cells were viewed every two days, until the transduction efficiency appeared to be increasing over time (data not shown). Another method used was to measure the percentage of positive GFP cells using the corresponding AlexaFluor488 fluorescence channel in the Countness ${ }^{\mathrm{TM}}$ Automated Cell Counter (Figure 3C). The highest transduction efficiency for B16-F10 cells was observed using the mosaic $\mathrm{rAAV} / \mathrm{DJ}$ vector under the control of CAG and was on average $81.3 \%$ (the scientific test was conducted in five independent experiments) (Figure 3C), while the lowest was found for the serotypes rAAV2/5, rAAV2/8, and rAAV2/1. Using real-time PCR, the number of copies of the ITR sequences were determined in both tumor and control cells (Figure 3G). The qPCR reaction was used with $50 \mathrm{ng}$ DNA/sample. The largest number of copies of the rAAV vector were observed in B16-F10 cells using the mosaic serotype under the control of CAG (with MOI=40000 the number of copies was about $7.4 \times 10^{7} / 50 \mathrm{ng}$ DNA/sample). The highest transduction efficiency in B16-F10 cells was also observed using enzyme-linked immunosorbent assays with approximately $8 \times 10^{5} \mathrm{pg} \mathrm{GFP} / \mathrm{ml}$ (Figure 3E). Statistically significant differences were noted between hybrid serotypes and the regular vectors $(* * * p<0.001)$ as shown in Figure $3 \mathrm{D}, \mathrm{F}$ and $\mathrm{H}$, where the dark grey color indicates the presence of statistically significant differences between the B16-F10 cells transduction performances and the light grey indicates the absence of statistically significant differences.

Assessment of the expression profile of lipid regulated genes in the B16-F1O and NIH/3T3 cells. The expression of lipid membrane transporters was evaluated. The tests were carried out in B16-F10 cells and the NIH/3T3 control cells. The $2^{-}$ $\Delta \Delta \mathrm{Cq}$ method was used to assess expression. Only the results that showed expression below 0.5 and above 2 were used for analysis. The highest fold change was observed for the genes Apoe (approx. 10.4) and Insigl (approx. 4.4). A significant decrease in the expression of Ptgs2 (approx. 0.002), Fads3 (approx. 0.008), Slc27a3 (approx. 0.008), Pla2gh4a (approx. 0.011), Alox15 (approx. 0.008), Slc16a16 (approx. 0.054), Slc27al (approx. 0.05), Nrlh3 (approx. 0.008) and Fabp5 (approx. 0.032) was observed. The results were normalized to the GAPDH housekeeping gene.

The expression of lipid regulated genes was also assessed. The $2^{-\Delta \Delta C q}$ method was used to assess gene expression. The control (non-transduced) and transduced B16-F10 cells were used for the analysis (Figure 4). Differences in fold changes were observed for a few genes. For example: regarding Hmgcs 1 , the use of the rAAV/DJ vector resulted in 1.17-fold increase in expression while the use of the $\mathrm{rAAV} / 2$ resulted in 0.7 -fold decrease in expression. In addition, a slight decrease in the expression of the Gyk gene was noticed only after transduction with the serotype rAAV2/2 (0.928). Differences in gene expression were also noticed for other genes: Hmgcr, the use of the serotype rAAV/DJ slightly increased expression by 1.028 , but the use of the serotype rAAV2/2 decreased expression by $0.81 ;$ Stard 4 , rAAV/DJ decreased expression by 0.382 while rAAV2/2 by 0.974 ; Slc16a6, expression was noticed only for serotype rAAV2/2; Slc27al, increased expression only after transduction rAAV/DJ; Fabp5, transduction with rAAV/DJ decreased expression by 0.536 while transduction with $\mathrm{rAAV} 2 / 2$ reduced expression by 0.899 ; Apoe, decreased expression by 0.823 upon transductions with the serotype rAAV/DJ (0.823) but increased expression by 1.320 upon transduction with the serotype $\mathrm{rAAV} 2 / 2$. In addition, we were noticed about 7.5-fold changes for the Abcal gene. The results were normalized to the Gusb housekeeping gene.

The expression of selected $A B C$ transporters was also evaluated in the B16-F1O and NIH/3T3 cells. The $2^{-\Delta \mathrm{Cq}}$ method was used to assess gene expression. Only the results that showd expression below 0.5 and above 2 were used for analysis. As shown in Table II, individual ABC transporters genes showed decreased expression. The lowest expression was noticed for the Tap2 (approx. 0.005) and Tapl genes (approx. 0.019). The results were normalized to the $18 \mathrm{~S}$ housekeeping gene.

In our study, the expression of mouse $\mathrm{ABC}$ transporters was also assessed. The $2^{-\Delta \Delta \mathrm{Cq}}$ method was used to assess gene expression. The test was performed on the control (nontransduced) and transduced B16-F10 cells. Fold changes were observed in a few genes (Figure 5). The highest fold was observed after transduction with the rAAV/DJ only for Tap2 (approx. 27.4), Tapl (approx. 14.465), and Abcd2 (approx. 13.16) genes. The fold changes were observed for $A b c a 5$ (approx. 2.938), Abcd4 (approx. 2.517), Absb9 (approx. 3.878), Abcdl (approx. 2.826) in the case of serotype rAAV/DJ. Interestingly, the levels of $A b s b 9$ were elevated by approx. 17.663 following transduction with the rAAV2/2. The elevated level of gene expression was observed for Abcg4, Abcal, Abca8a, Abcb4, both after transduction with the $\mathrm{rAAV} / \mathrm{DJ}$ and $\mathrm{rAAV} 2 / 2$. The results were normalized to the Hprt1 housekeeping gene.

Transduction efficiency of $r A A V / D J$ and $r A A V 2 / 2$ serotypes in vivo.

In vivo results of $\mathrm{rAAV}$ vector transduction are shown in Figures 6,7, and 8 .

Based on the selection of a rAAV vector of $\mathrm{rAAV} / \mathrm{DJ}-\mathrm{CAG}$, which showed the highest tropism in the direction of melanoma B16-F10 cells in in vitro studies (Figure 3), in vivo studies were conducted. The B16-F10/rAAV/GFP transductants were tested. As shown in Figure 6, after subcutaneous administration of the transductants, the presence of about $1.19 \times 10^{4}$ copies of $\mathrm{rAAV} / 50 \mathrm{ng}$ DNA/total sample was found, which was about 10 times less compared to that seen with intravenous administration. Statistically significant differences were observed at the level of $* p<0.05$. 

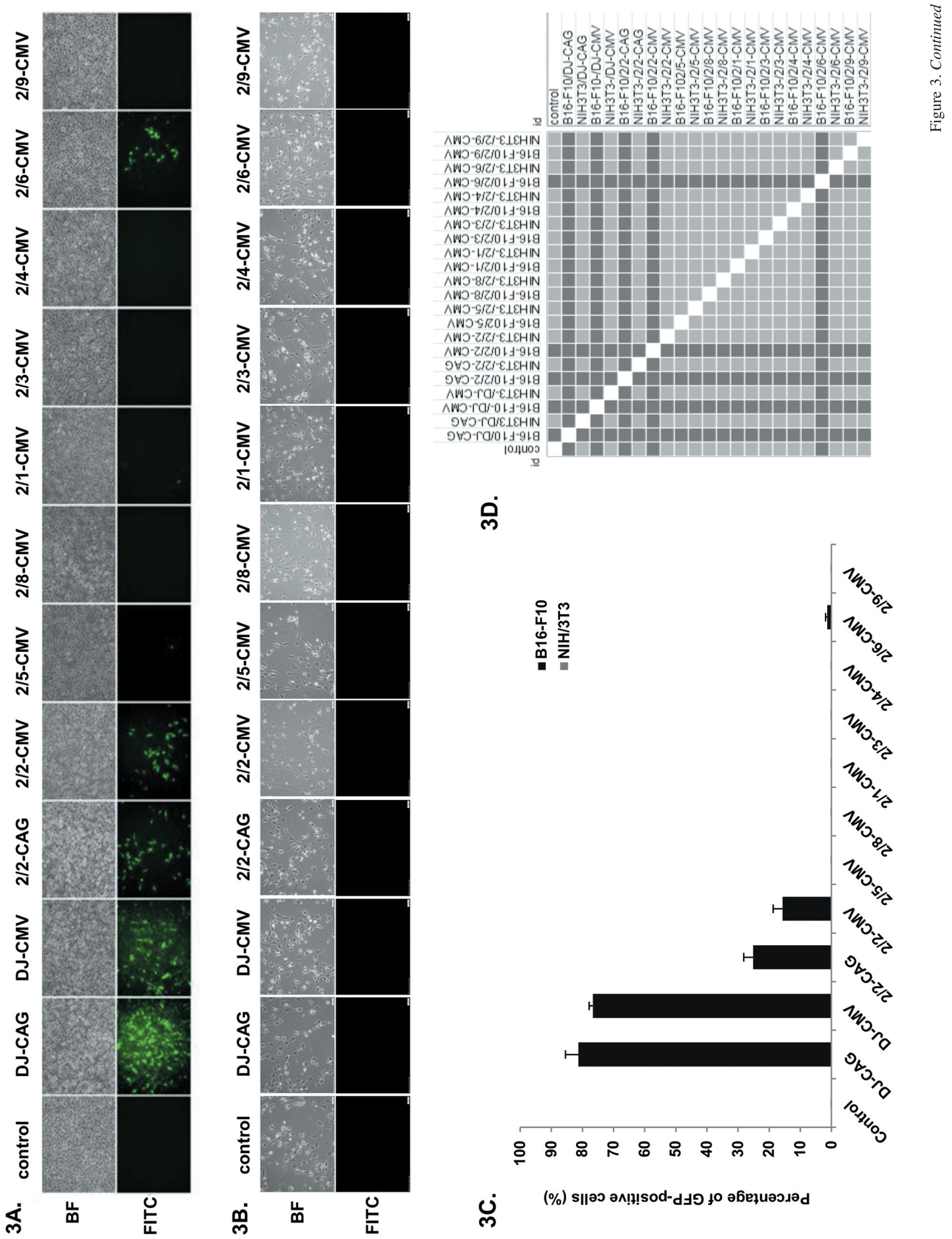

ن

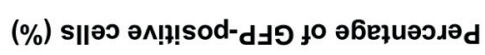



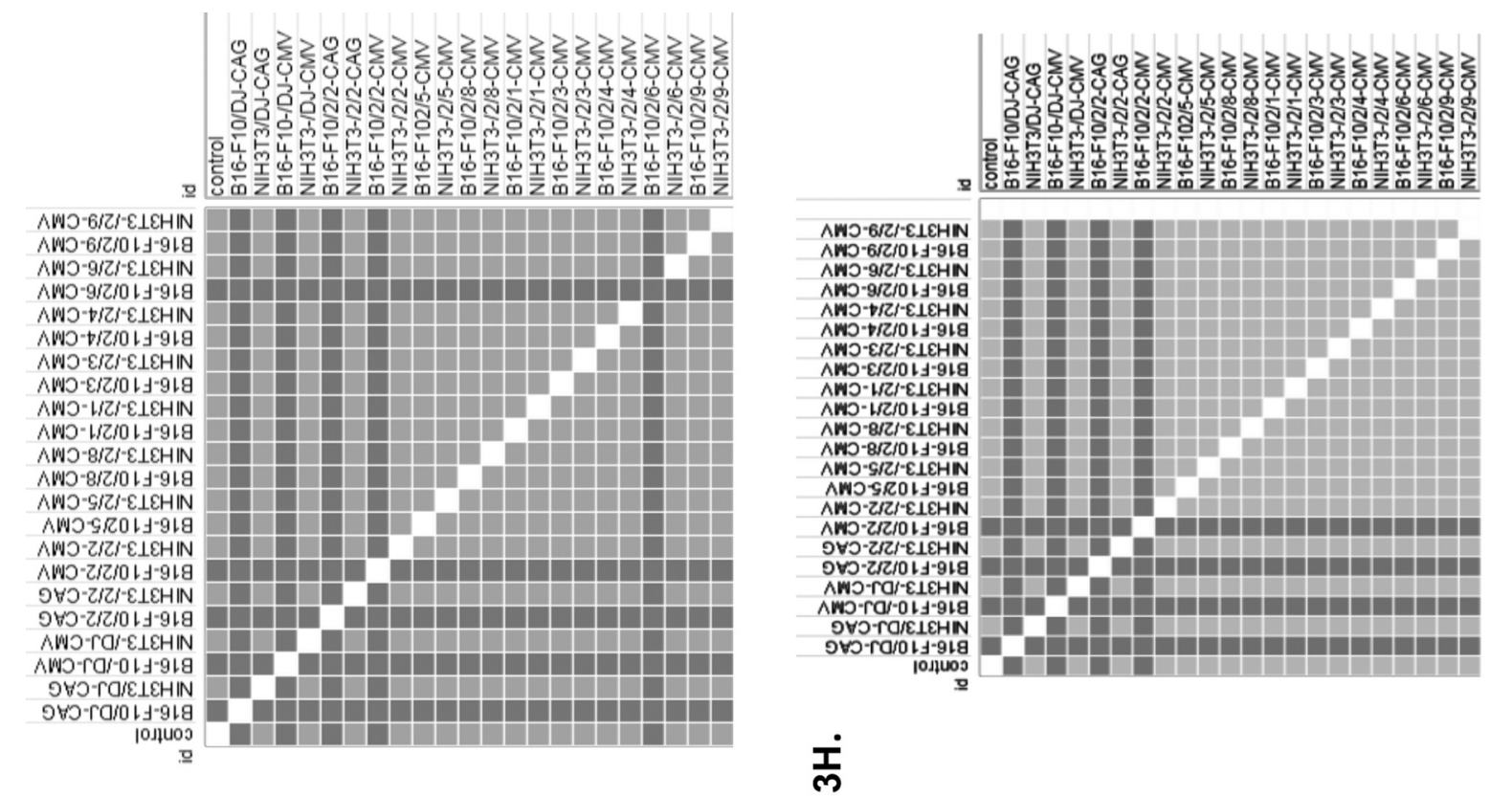

\section{峁}

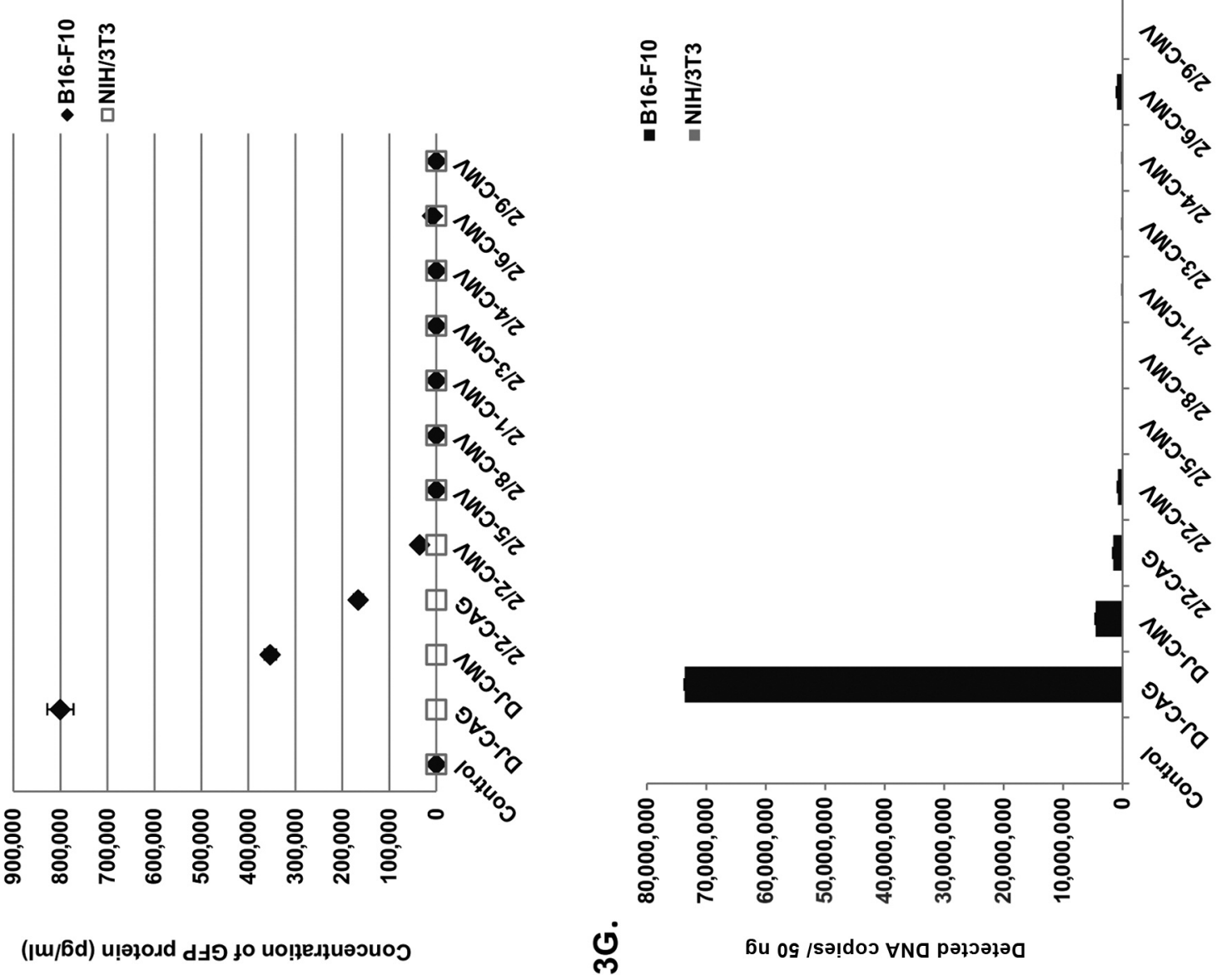




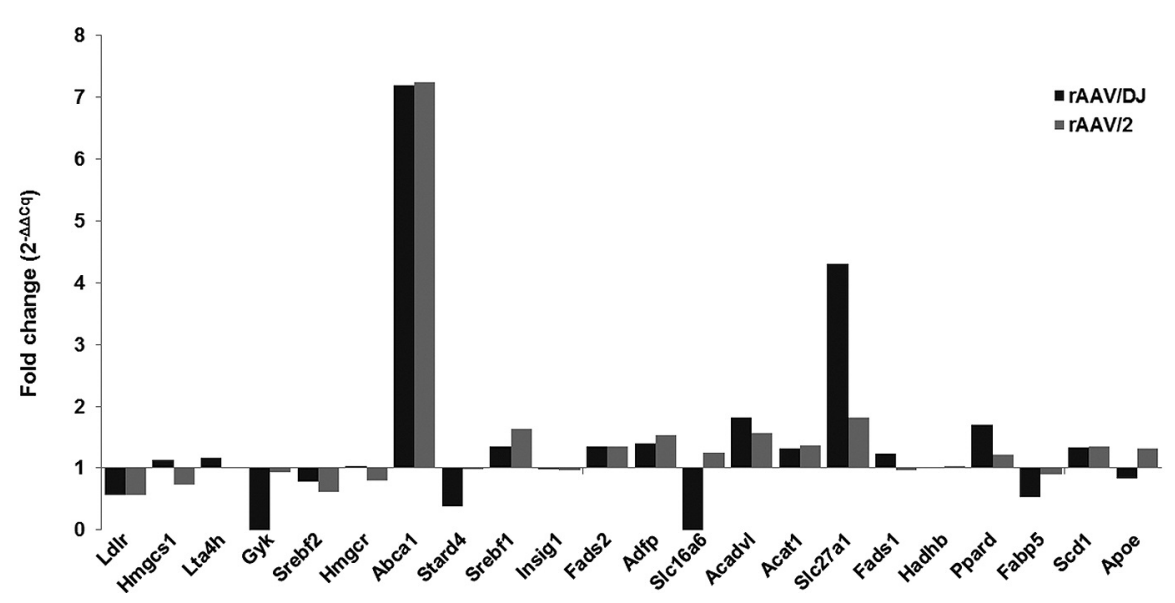

Figure 4. The relative expression of lipid regulated genes in B16-F10 cells after transduction with the rAAV vectors compared to non-transduced B16F10 cells (defined as 1-fold change).

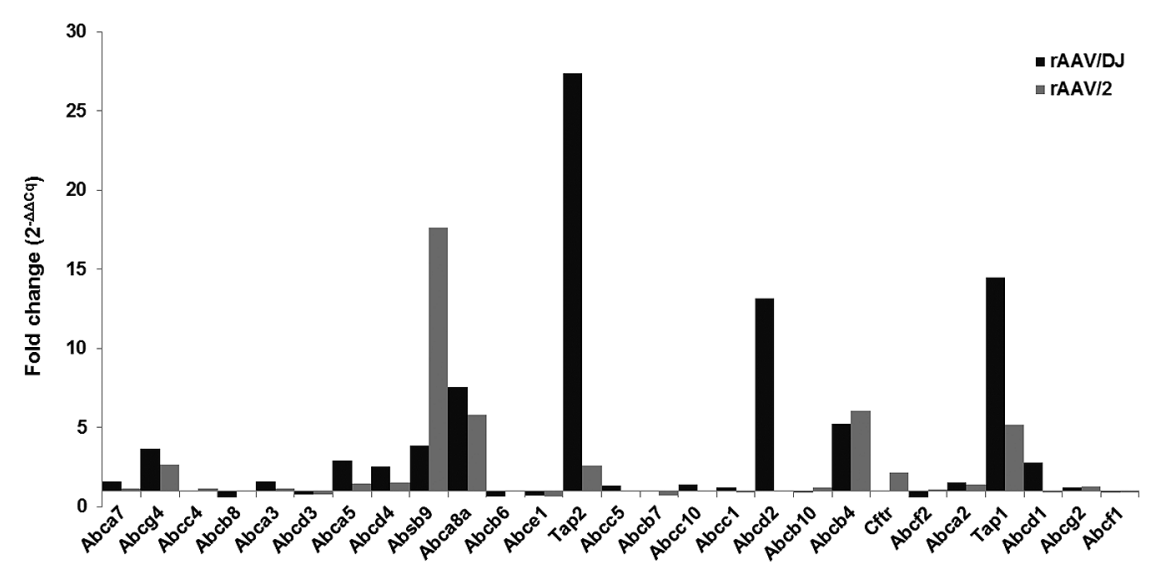

Figure 5. The relative expression of ABC transporters in B16-F10 cells after transduction with the rAAV vectors compared to non-transduced B16-F10 cells (defined as 1-fold change).

Based on the in vitro studies, we chose the serotypes with the highest tropism for mouse melanoma B16-F10 cells. Animal studies were conducted in three independent experiments. Two models of melanoma were proposed: metastatic and subcutaneous. In a model that had been developed in the lungs, B16-F10 cells, cultured under standard conditions $\left(37^{\circ} \mathrm{C}\right.$ and $5 \%$ $\mathrm{CO}_{2}$ ), were administered in the concentration of $3 \times 10^{5}$ per mouse/tail vein. After about 14 days, metastases were observed in the lungs. At that time, we administered rAAV preparations at a dose of $10^{10} \mathrm{gc} /$ mouse using both the intranasal and intraperitoneal routes. Seven days after administration, we collected pulmonary tissue and other organs for assessing the transduction efficiency and biodistribution of the preparations (Figure 1A). To evaluate the effectiveness of the rAAV infections, we used the qPCR method with the pAAV-IREShrGFP vector as a standard curve. The results (Figure 7A and C) depict the highest efficiency of the rAAV/DJ vector under control of the CAG promoter, which was obtained after intranasal administration of approximately $1.33 \times 10^{4}$ copies/50 ng DNA/sample and intraperitoneal administration of $5.49 \times 10^{3}$ copies/50ng DNA/sample. Intranasal administration (Figure 7A) was more effective compared to intraperitoneal administration $(* * p<0.01)$. Based on the presented results (Figure 3A, C, E, G), it can also be concluded that higher transduction efficiency is observed after introduction with $\mathrm{rAAV} / \mathrm{DJ}$ and $\mathrm{rAAV} 2 / 2$ containing the CAG promoter. In the model of skin melanoma, we used both the intratumoral (Figure 7G) and intravenous (Figure 7E) route of administration of rAAV vectors. After intravenous administration (Figure 7E) the vectors were administered at a concentration of $10^{10} \mathrm{gc} /$ mouse tail vein. Seven days after administration of the rAAV vectors, tumors and other organs were collected to estimate rAAV biodistribution. The 


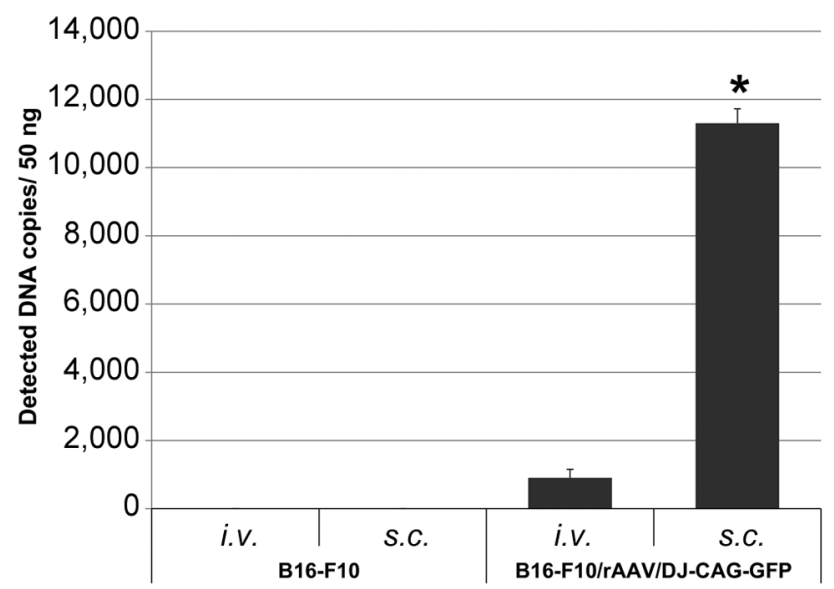

Figure 6. Increased number of rAAV copies in the tumors after B16/F10/rAAV/DJ-CAG-GFP intravenous (iv) or subcutaneous (s.c.) administration.

greatest transduction efficiency was observed after the administration of rAAV vectors directly to the tumor tissue and was approximately $1.13 \times 10^{4}$ copies/50 ng DNA/sample (Figure $7 \mathrm{G})$, which confirms in vitro results. Based on the in vivo studies, we demonstrated the highest efficiency of the rAAV/DJ under control of the CAG promoter using all routes of administration. The most effective was intranasal delivery of rAAV to melanoma cells in the lungs (Figure 7A). The control laboratory animals were administered $0.9 \% \mathrm{NaCl}$. Results are not presented because no copies of the ITR sequence were observed.

Mice received $10^{10}$ genome copies of rAAV by intranasal or intraperitoneal administration. GFP expression was assessed in metastatic lung cells at 7 days after vector administration by anti-GFP immunohistochemical analysis. Immunohistochemical staining was used to estimate the presence of rAAV vectors. Antibodies were used against both lung metastatic melanoma cells (see tumor marker) and against the GFP protein (see GFP immunodetection). As shown in Figure 8, GFP protein expression was observed in metastatic melanoma cells only when $\mathrm{rAAV} / \mathrm{DJ}$ was administered by both the intranasal and intraperitoneal route.

It is interesting that the highest transduction efficiency in the lung tissue in in vitro conditions was recorded after the intranasal administration of the $\mathrm{rAAV} / \mathrm{DJ}$ serotype (this is also shown in Figure 7). In Figure 8 we can also observe a stronger effect of the CAG promoter on melanoma cell metastases to the lungs.

\section{Discussion}

Melanoma is an aggressive malignant tumor formed by the uncontrolled growth of melanocytes. It is one of the deadliest forms of skin cancer. The most common location of melanoma
Table I. The relative expression of lipid regulated genes in B16-F10 cells compared to NIH/3T3 cells (defined as 1-fold change).

\begin{tabular}{lcc}
\hline Gene & $\begin{array}{c}\text { Increased expression } \\
\text { (fold change) }\end{array}$ & $\begin{array}{c}\text { Decreased expression } \\
\text { (fold change) }\end{array}$ \\
\hline Ptgs2 & 0.002 \\
Hmgcs1 & 0.456 \\
Gyk & 0.108 \\
Fads3 & 0.008 \\
Abca1 & 0.113 \\
Slc27a3 & 0.008 \\
Stard4 & 0.401 \\
Insig1 & & \\
Pla2gh4a & 4.397 & 0.011 \\
Alox15 & & 0.008 \\
Slc16a16 & 0.054 \\
Acadv1 & & 0.258 \\
Slc27a1 & & 0.05 \\
Fads1 & & 0.274 \\
Nr1h3 & 0.008 \\
Hadhb & & 0.286 \\
Ppard & & 0.375 \\
Fabp5 & & 0.032 \\
Scd1 & & 0.32 \\
Apoe & & \\
\hline
\end{tabular}

Table II. The relative expression of ABC transporters genes in B16-F10 cells compared to NIH/3T3 (defined as 1-fold change).

\begin{tabular}{|c|c|c|}
\hline Gene & $\begin{array}{l}\text { Increased expression } \\
\quad \text { (fold change) }\end{array}$ & $\begin{array}{l}\text { Decreased expression } \\
\quad \text { (fold change) }\end{array}$ \\
\hline Abca7 & & 0.130 \\
\hline Abca3 & & 0.253 \\
\hline$A b c d 3$ & & 0.258 \\
\hline Abca5 & & 0.180 \\
\hline$A b c d 4$ & & 0.320 \\
\hline Tap2 & & 0.005 \\
\hline$A b c c 5$ & & 0.269 \\
\hline Abcc10 & & 0.105 \\
\hline$A b c c 1$ & & 0.382 \\
\hline Abcb10 & & 0.145 \\
\hline$A b c f 2$ & & 0.859 \\
\hline Abca2 & & 0.526 \\
\hline Tapl & & 0.019 \\
\hline$A b c d 1$ & & 0.167 \\
\hline Abcg2 & & 0.269 \\
\hline$A b c f 1$ & & 0.715 \\
\hline
\end{tabular}

is the skin, but it shows relatively high tendencies to metastasize outside the original location (67). The prognosis of patients with metastases to the lungs is particularly unfavorable and the survival rate of patients is very low (68, 69). For this reason, innovative solutions are being sought for the treatment of melanoma metastases to the lungs. 
In modern times, one of the promising and alternative approaches to the treatment of many diseases, including cancer, is gene therapy. One of the gene therapy strategies used in cancer, including a form that metastasizes to the lungs, is the administration of viral vectors carrying therapeutic genes through the intranasal route (39). It is a promising method of treatment (administration) and for the identification of cancer cells in the lungs. Its additional advantage is the high safety of administration and the selectivity of gene transfer directly to bronchial tree cells $(40,70-73)$. The success of gene therapy is determined by the safe and effective introduction of a therapeutic transgene into cells (74). One of the current methodological challenges is the selection of an appropriate vector that, when introduced to the target cell, will have a high transduction efficiency (75). Scientists have been constantly working on developing appropriate gene carriers that will produce the desired results and meet the challenges associated with gene delivery (74). To date, viral vectors are the most common vectors for gene transfer. Their high transduction efficiency of cells has been determined. However, they can sometimes be problematic when it comes to their use in clinical trials, due to their immunogenicity and toxicity $(69,75,76)$. Among the viral carriers, great interest has been shown for adeno-associated viruses, rAAV, due to their high safety profile. They can be used for gene therapy of metastatic lung tumors such as melanoma, which has been shown in post-mortem analysis that in as much as $70 \%$ of cases metastasizes to the lungs $(38,77)$. In our studies, rAAV/GFP vectors were used to identify the melanoma cells that metastasize to the lungs. The tests were conducted in both in vitro (Figures 3, 4, and 5) and in vivo conditions (Figures 6,7, and 8). The experiment diagram is presented in Figure 1. In the analysis of the transduction efficiency, several rAAV serotypes were used in in vitro cultures, as well as in in vivo conditions in two melanoma models: skin and metastatic. It was established that B16-F10 cells were transduced both in in vitro and in vivo conditions with the highest efficiency by using the rAAV/DJ-GFP serotype. Most likely, this is related to the construction of the capsid. It is known that the construction of individual vector capsids affects the efficiency of gene transfer to cells, as has been indicated in previous studies $(12,33-36)$. The high transduction of mouse melanoma cells of approximately $80 \%$ (Figure 3C) that was demonstrated in this work may suggest that there are specific characteristic rAAV receptors on the surface of B16F10 cells. In the studies of Tsoukalas et al. in B16-F10 cells, the presence of receptors such as sialic acid (78), heparin sulfate (79), gangliosidine (80), FGFR (81), VEGFR (82) and $\alpha \mathrm{V} \beta 5$ integrins (83) has been demonstrated. The rAAV/DJ vector consists of rAAV2, rAAV4, rAAV5, rAAV8, rAAV9 and avian, bovine and goat serotypes (34). Szmidt et al. have described one of the vectors that belongs to AAV/DJ- BAAV (84). In their studies, they have shown that the main receptor for BAAV is the ganglioside receptor. This receptor is also present on the surface of B16-F10 cells (80), and a higher transduction efficiency was observed in these cells as compared to mouse fibroblast cells. As reported by Fishmann et al. there are no gangliosides on the surface of NIH/3T3 cells (85). In our experiments, the transduction efficiency of NIH/3T3 cells was almost imperceptible (Figure 3). An additional advantage that can result in such high transduction in mouse melanoma cells is the presence of serotypes that infect B16-F10 cells using HSPG and sialic acid (respectively rAAV2, rAAV4 and rAAV5 serotypes) (86-88). In addition, caprine AAV capsid is $94 \%$ similar to the rAAV5 capsid, and has also high transduction efficiency in the above-mentioned cells (89). Van Lieshout et al. have indicated the presence of a proteoglycan receptor for laminine, which in the context of our research may explain the increase in the transduction of B16-F10 cells by the hybrid serotype rAAV/DJ in vitro (Figure 3) and in vivo (Figures 6, 7 and 8) (72). Effective design of gene therapy involves not only the selection of the right vector, but also the selection of the right promoter. In the rAAV construction, common promoters are used, which include, among others, CMV, EF1a, SV40 or CAG (90). In our research, we focused on the use of CMV and CAG promoters. The choice of a promoter is extremely important in targeted gene therapy and, thus, in the individualization of treatment (90-92). We noticed that improved transduction efficiency in melanoma cells in in vitro and in vivo conditions was obtained by the CAG promoter (Figures 3, 7, and 8). This may be related to published observations that some promoters are silenced in certain cell types (93). The importance of choosing the right promoter has also been shown by Grey et al., where the CMV promoter, compared to CAG, was silenced in the central nervous system cells (93). These studies noted that the CAG promoter is a stronger promoter in CNS cells and other cell types. The fact that the CAG promoter is more efficient as compared to other promoters has also been noted in the study of Alton et al., were the promoter's impact on the efficiency of transduction was also demonstrated (94). In that study, the authors also showed the importance of the route of administration and its effect on the transduction of several cell types.

Figure 7. Transduction efficiency of the rAAV/DJ and rAAV2/2 vectors driven by the CAG and CMV promoters. The results are shown as mean \pm standard deviation. Statistically significant differences were observed between particular serotypes; at the significance level $* * p<0.01$. (A and $C$ ) results show the transduction efficiency of the $r A A V$ vectors in the lung metastatic melanoma, including intranasal $(A)$ and intraperitoneal $(C)$ route of administration. ( $E$ and $G$ ) results present transduction efficiency in cutaneous tumors $(E)$ using the intravenous route of administration and the intratumoral $(F)$ route of administration. $(B, D, F, H)$ results show the biodistribution of particular $r A A V$ vectors to mice organs. 
A

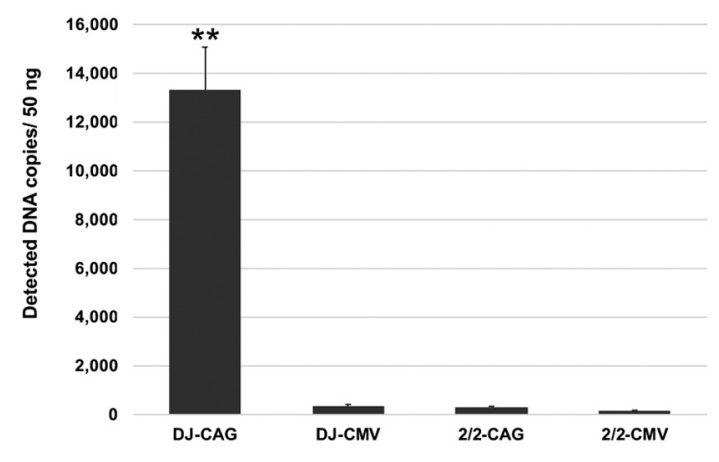

C
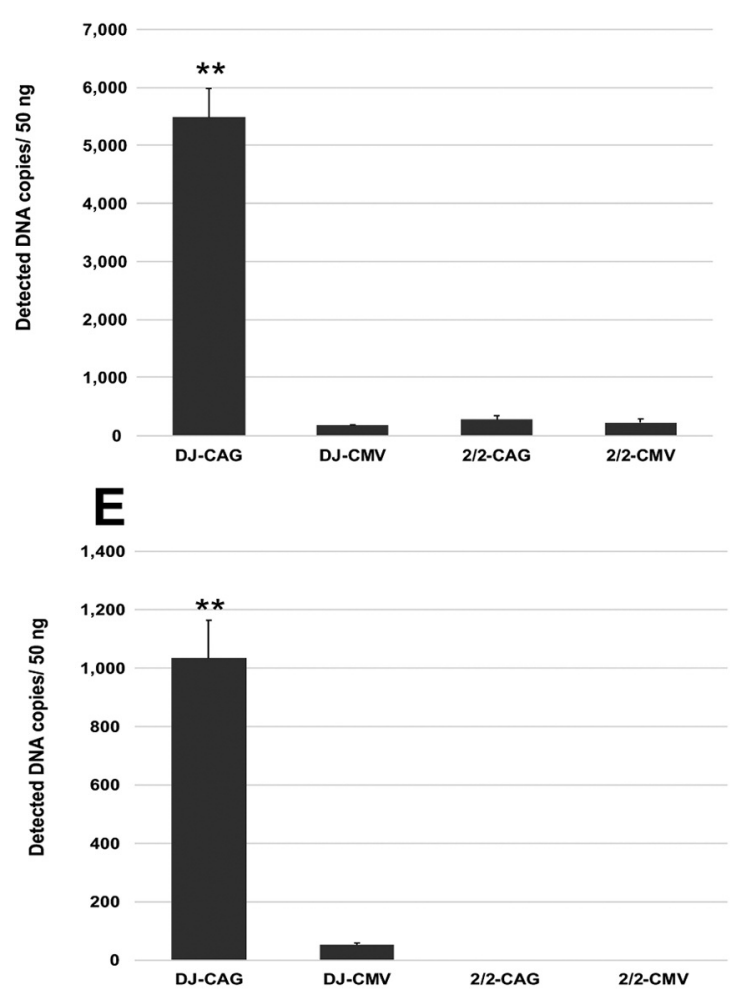

\section{G}

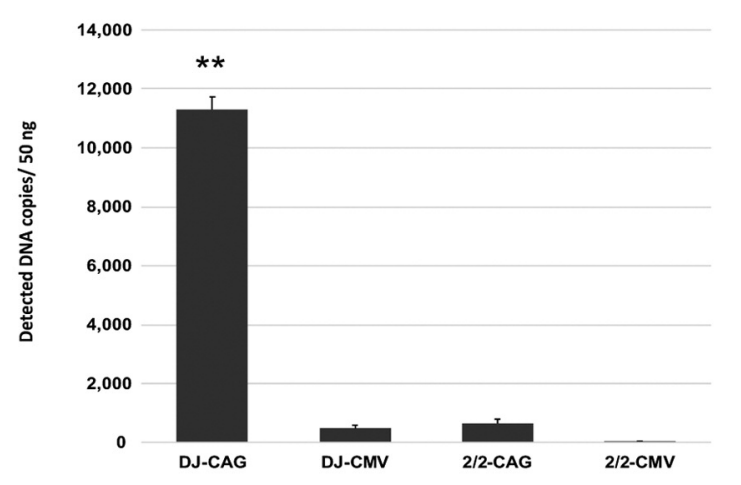

B

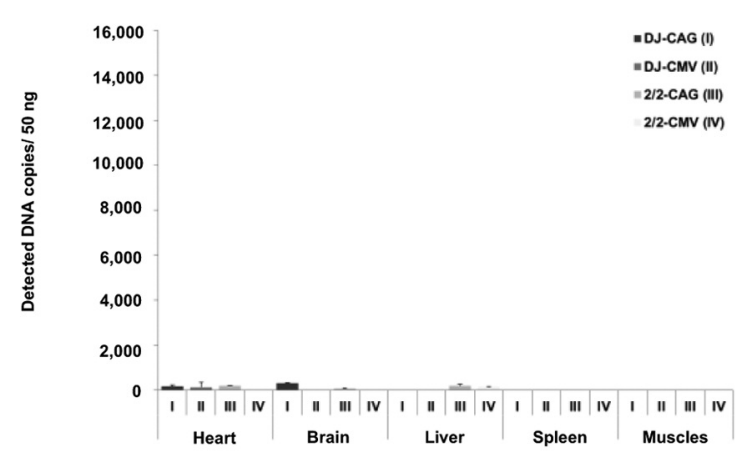

D

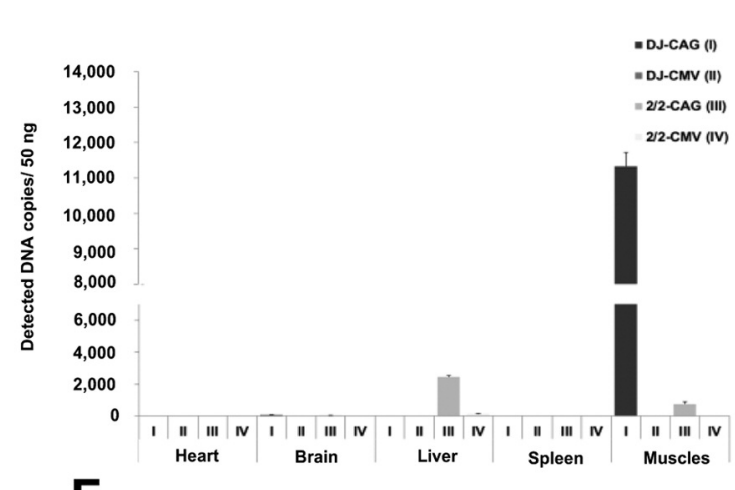

F

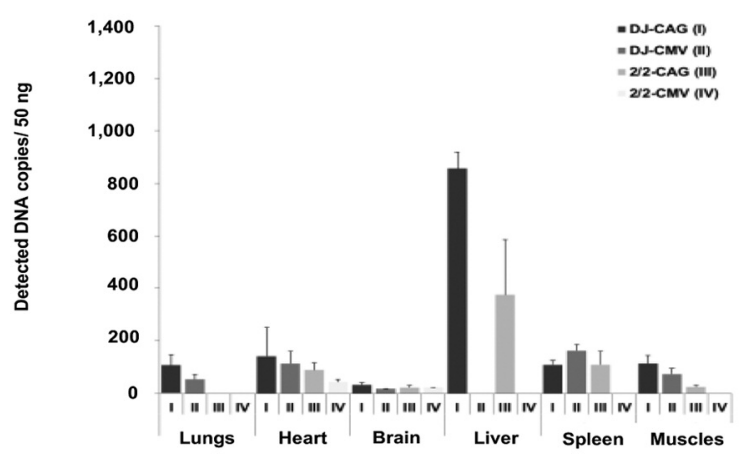

H

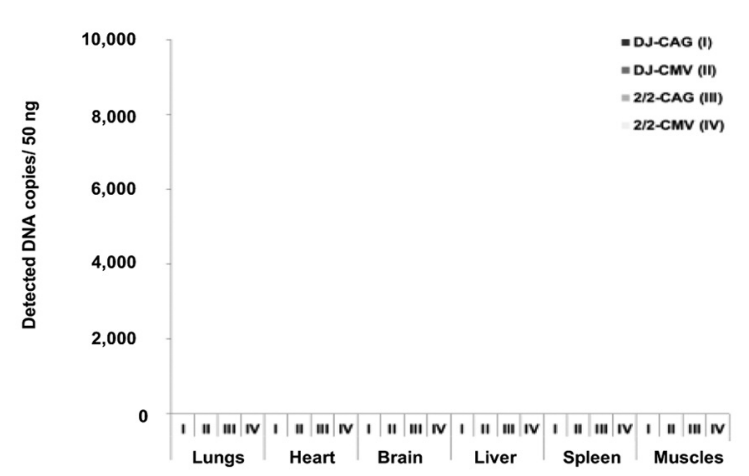


The results of the in vitro transduction efficiency are presented in Figure 3, which shows that the transduction efficiency of B16-F10 cells measured using the Automated Cell Counter (Figure 3C) for the rAAV1-rAAV6 and rAAV9 vectors does not coincide with the number of copies of the ITR sequence measured using the qPCR method (Figure 3G). Such results may be the result of degradation by the ubiquitinproteasome (36). Therefore, the qPCR method may show the number of copies for each serotype (Figure $3 \mathrm{G}$ ), but the expression of the GFP protein in the cells can be decreased as presented in Figure $3 \mathrm{~A}, \mathrm{C}$ and E. It is interesting that the rAAV/DJ vector showed high transduction efficiency both using the positive GFP cells measurement method (about $80 \%$ ) (Figure 3C) and the qPCR method (approx. $7 \times 10^{7}$ genome copies) (Figure 3G). For this reason, scientists are considering vectors that can avoid degradation within the cell and demonstrate effective expression. A positive candidate is the hybrid vector $\mathrm{rAAV} / \mathrm{DJ}$, which can avoid degradation by the proteasome by bypassing phosphorylation and then ubiquitination as has been shown by Mao et al. (36). The rAAV transduction efficiency also depends on the intracellular factors described by Nonnenmacher et al. among which we can mention, inter alia, membrane cholesterol, actin, Cdc42, Arf1, GRAF1, Rab proteins, PLA2, CLIC/GEEC pathway and others (95). In our research, the expression of lipid genes and $\mathrm{ABC}$ transporters was assessed. Fold change results are shown in Table I, Table II, Figures 4 and 5. On the basis of the results gathered in Table I, increased fold changes in the expression of the genes Insigl (approx. 4.4) and Apoe (approx. 10.4) in B16-F10 cells was observed compared to NIH/3T3 cells.

A potential increase in the expression of the Insigl gene may promote increased rAAV transduction through increased cholesterol synthesis. As it has already been mentioned by Nonnenmacher et al., the amount of membrane cholesterol may indirectly promote increased infection by viral vectors (95). Zhang et al. have shown the relationship between increased expression of the Insigl gene in HIV-1 infection (96). These studies showed that virus infection regulates sterol synthesis as a strategy to facilitate viral replication.

In addition, an increase in the expression of the SREBF1 gene in cells after transduction (Figure 4) was observed, which was related to the Insigl gene (Figure 9). This gene plays a key role in binding to the sterol regulatory elements of about 30 genes needed to capture and synthesize cholesterol and fatty acids (96). Its increase in expression may promote the internalization of rAAV vectors in B16-F10 cells compared to the NIH/3T3 control cells (Table I). Liu et al. have also observed an increase in Insigl expression before virus infection (97).

In addition, in non-transducted B16-F10 cells an increase in the rate of the Apoe gene (Table I) compared to NIH/3T3 cells was noted. Siddigui et al. have shown that the increase in the expression of this gene can affect the growth of cell infections by HIV by increasing its production (98). This was related to an increase in the location of viral envelope proteins on the surface of cells. As has been shown by Siddigui et al., a decrease in Apoe expression may cause vector degradation in lysosomes (98). These studies may indicate that mouse melanoma cells are prone to transduction by the rAAV vector. Qiao et al. have presented results of silencing of the Apoe gene (99). Inhibition of its expression causes as much as $90 \%$ decrease in infection by $\mathrm{HBV}$ virus in liver cells. It is speculated that Apoe can play a role in HBV's persistent infection by avoiding the host's immune response. On the other hand, the study by Kivela et al. has shown that high levels of lipoproteins reduce transduction by adenoviruses (100). Furthermore, Lefevre et al. have shown the relationship between Apoe and the HSPG receptor, which promotes infection by the HCV vector (101). Viral vectors use, among other mechanisms, endocytosis for cell transduction and proteins, such as clarines, caveolae, dynamine, and Rac, play a significant role (95).

The relationship between lipid related genes, the proteins involved in effective transduction and receptors for $\mathrm{rAAV}$ are presented in Figure 10.

Long et al. have suggested that the increase in the multiplication factor of the Abca 1 gene (Figure 4, Table I) on the cell membrane increases infection by rAAV vectors (102). This is because this gene together with Apoe regulates cholesterol levels, which can enable the survival of the rAAV vector in cells. They can probably use cholesterol as the main component of survival. We noted that the Abca1 protein is associated with proteins that are responsible for the internalization of the rAAV virus in the cell (Figure 10B). This may suggest that the transduction of B16-F10 cells with the use $\mathrm{rAAV} / \mathrm{DJ}$ vector results in an increase in the expression of the Abcal gene (Figure 4, Table I), which activates the proteins responsible for increasing efficiency by the aforementioned vector. On the other hand, we see an increase in the multiplication factor of the Slc27al gene in transduced cells (Figure 4), which is not directly related to the proteins responsible for the efficient transduction by rAAV (Figure 10A). However, it is responsible for the increase in proteins transporting fatty acids, which can also be considered a factor that increases the transduction efficiency e.g. upon the administration of a next dose. The studies of Arnold et al. and Aqil et al., which showed an increase in the expression of this gene after a chickenpox infection and HIV, respectively, support the validity of our claim $(103,104)$.

The relationship between $\mathrm{ABC}$ transporters, proteins involved in effective transduction, and receptors for $\mathrm{rAAV}$ is presented in Figure 11.

Based on the analysis of the expression of $\mathrm{ABC}$ transporter genes, as demonstrated in Figure 11, there is no relationship between the expression of the genes of $\mathrm{ABC}$ transporters, B16-F10 cell receptors for $\mathrm{AAV}$ vectors or for intracellular proteins promoting efficient transduction. 


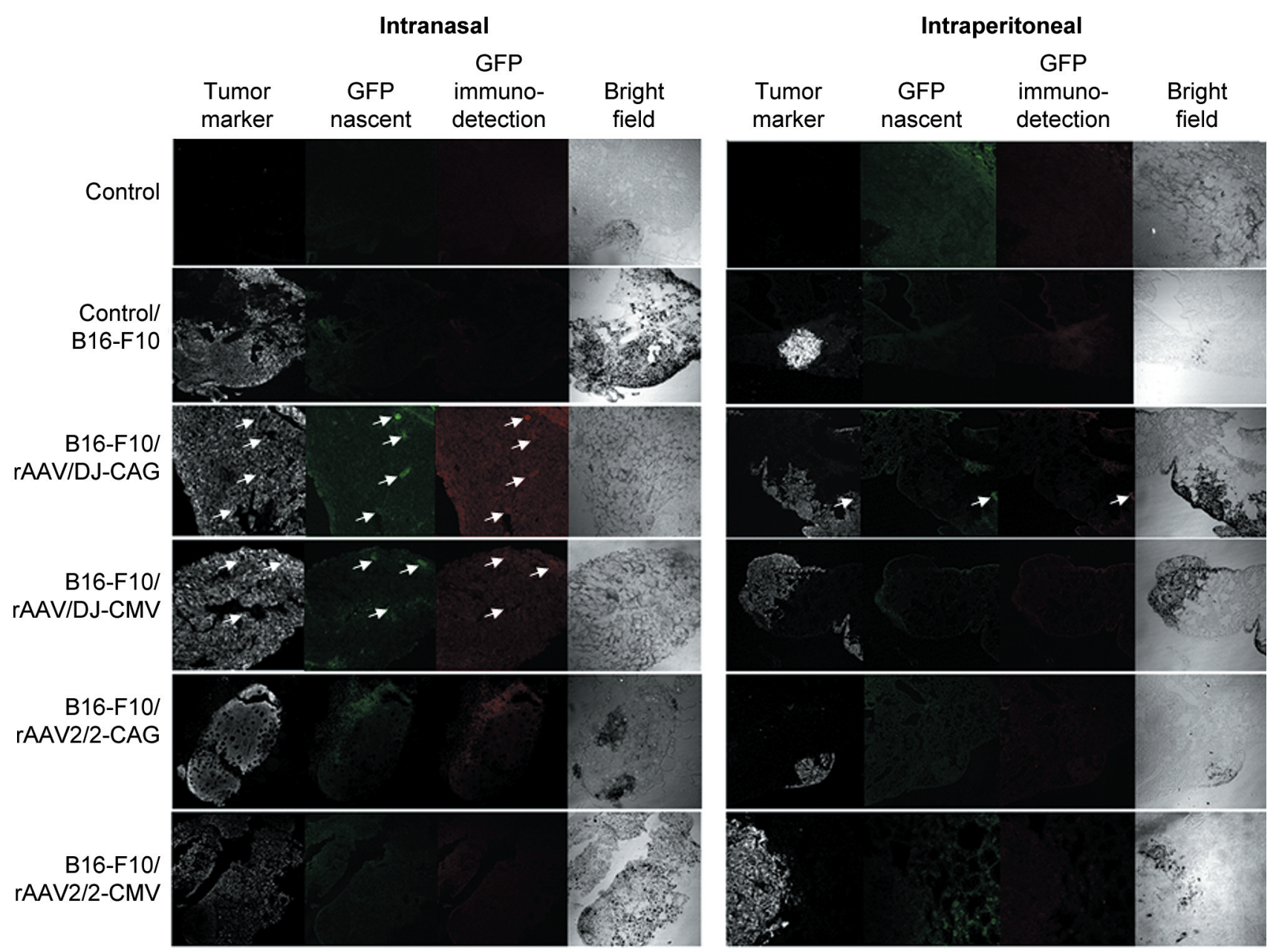

Figure 8. GFP-expression in metastatic melanoma cells to the lungs after intranasal and intraperitoneal rAAV delivery. Arrows indicate GFP expression, which confirm rAAV transduction.

Several in vivo tests were conducted as part of this study. The results are presented in Figures 6, 7, and 8. Different routes of administration of viral vectors to estimate the most favorable marking of B16-F10 cells by a vector encoding green fluorescence protein were used in the tests. Figure 7A, 7C and 8 show that higher transduction efficiency of B16F10/lungs by rAAV-GFP vectors is observed after intranasal administration (approx. $1.33 \times 10^{4} \mathrm{gc} / 50 \mathrm{ng} / \mathrm{DNA}$ total/sample DNA) compared to intraperitoneal administration $\left(5.49 \times 10^{3}\right.$ $\mathrm{gc} / 50 \mathrm{ng} / \mathrm{DNA}$ total/sample). To understand the obtained results, one can refer to the specific anatomy of the respiratory system. Thanks to the highly vascularized nasal cavity, it is possible to quickly and directly introduce drugs, as well as gene preparations into the lungs $(42,94)$.

In addition, intranasal administration directs the preparation directly to the bronchial tree without the first pass effect and the possible potential loss of genome copies of rAAV vectors in the body (42-49). Our study indicated that transduction efficiency is influenced by the vector, promoter and route of administration as has also been shown by Belur et al. (64) who have demonstrated that the CAG promoter is more effective (64). The expression of CAG promoter in the lungs lasted up to 12 months while that of CMV expression up to 8 months. However, the CMV promoter has an immediate effect that provides strong but short-term expression $(90,91)$. However, it is very susceptible to silencing in some cell types (89). The effectiveness of the CAG promoter is shown in Figure 3, 7, and 8. The Kurosaki et al. studies support the effectiveness of the CAG promoter in respiratory cells (91). In their studies, the AAV6 vector with the aforementioned promoter was constructed, which effectively infected cells of the respiratory system. A slightly inconsistent transduction may be recorded after intranasal administration in case of animals because some rAAV vectors can stay in the upper respiratory tract and some 

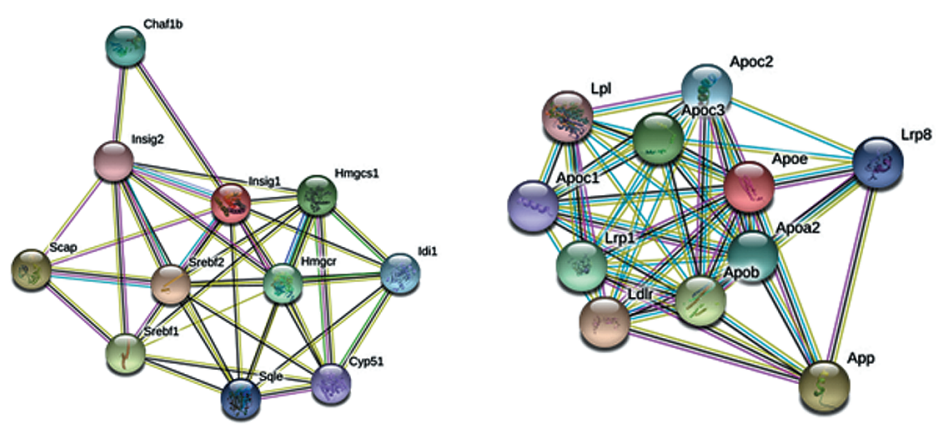

Figure 9. The relationship between lipid regulated genes and proteins present in the cell. Scheme made on the basis of the STRING program. Network nodes represent proteins: splice isoforms or post-translational modifications are collapsed, i.e. each node represents all the proteins produced by a single, protein-coding gene locus. Node color: colored nodes: query proteins and first shell of interactors. White nodes: second shell of interactions. Empty nodes: proteins of unknown 3D structure. Filed nodes: some 3D structure is known or predicted. Edges represent protein-protein associations: associations are meant to be specific and meaningful, i.e. proteins jointly contribute to a shared function; this does not necessarily mean they are physically binding each other. Known interactions: blue: from curated databases, pink: experimentally determined. Predicted interactions: green: gene neighborhood; red: gene fusions; dark blue: gene co-occurrence. Others: yellow: textmining; black: co-expression; violet: protein homology.

of them get into the digestive system (Figure 7D). For this reason, we can determine a lower number of copies than the output number (as shown on Figure 7A); we administered $10^{10}$ genome copies of rAAV and detected about $10^{4}$ copies.

As a result, this may cause a decrease in the expression of the GFP protein in the lower respiratory tract (Figures 7,8) as has also been shown in similar studies by Kurosaki et al. (91). A significant factor influencing transduction efficiency after e.g. intranasal administration, as has been mentioned before, is the way of administration (Figure 2) to laboratory animals, where the vector enters in a fraction of the cells in an appropriate way. The apical part of epithelial cells of the respiratory system is rich in receptors for sialic acid, while the basal-lateral part in HSPG, therefore one can observe differences in the efficiency between $\mathrm{rAAV} / \mathrm{DJ}$ serotype and rAAV/2/2 (Figure 7A, C) (91). In the case of the rAAV/DJ serotype, its capsid is rich in amino acid residues recognized by receptors in both the apical part of the cells and the basallateral part. Therefore, one can observe its higher efficiency after intranasal administration (Figure 7A, 8) as well as using the intraperitoneal route (Figure 7C, 8). Santry et al. have evaluated various methods of administration to the respiratory tract of laboratory mice (40). Some of the studies have also examined the route of intranasal administration. They demonstrated that after intranasal administration, the best efficiency, consistency and reproducibility in the distribution of the vector in the lungs was recorded. Depending on the goal of transduction and the preferred target location, one should choose the right method of gene administration. Choosing the right method will make it possible to increase the transduction efficiency and achieve consistent results. As Santry et al. have described, the intranasal route is the safest route of administration due to the absence of inflammatory foci and any other complications (40). The result may also be influenced by the volume-dependent distribution of the vector. The distribution of the vector in the lungs depends on the volume of the substance delivered to the nasal cavity after intranasal administration. The study by Santry et al. has shown that the position in which animals are kept during administration is also of importance (40). In our experiment, as Figure 2 shows, the preparation was administered in a volume of $30 \mu$ while the mouse was held in a vertical position. If mice are held in an inappropriate way during administration, the delivery of the vector to the lungs may be ineffective. When comparing Figure $7 \mathrm{E}$ and $\mathrm{G}$, one can notice a higher transduction efficiency of rAAV/DJ vector after intratumoral administration (approx. $1.13 \times 10^{4} \mathrm{gc} / 50 \mathrm{ng} \mathrm{DNA} / \mathrm{sample}$ ) compared to intravenous administration (approx. $1 \times 10^{3} \mathrm{gc} / 50 \mathrm{ng}$ DNA/sample). Local (topical) high concentration of vector explains the high transduction of melanoma cells. The rAAV/DJ vector tropism towards mouse melanoma cells was also confirmed in our in vitro studies (Figure 3). The presence of antibodies neutralizing rAAV serotype 2, which automatically decreases its transduction performance, could be another reason for the fact that the rAAV/DJ vector is more effective in infecting B16-F10 cells in in vivo conditions than the rAAV2/2 vector $(93,105)$. The use of hybrid vectors is becoming increasingly important due to their unique characteristics such as the lack of immune system reaction since they possess the ability to avoid neutralizing antibodies thanks to the construction of their capsid. For instance, van Lieshout et al. have demonstrated that the triple mutant capsid of the rAAV6 vector, containing mutations F129L, Y445F and Y731F is ideal as a candidate for gene therapy of the the lungs (106).

In conclusion, our research showed high tropism of the rAAV/DJ vector for mouse melanoma cells both in vitro and in vivo. The highest efficacy of infection after intranasal administration was observed towards melanoma metastasizing 


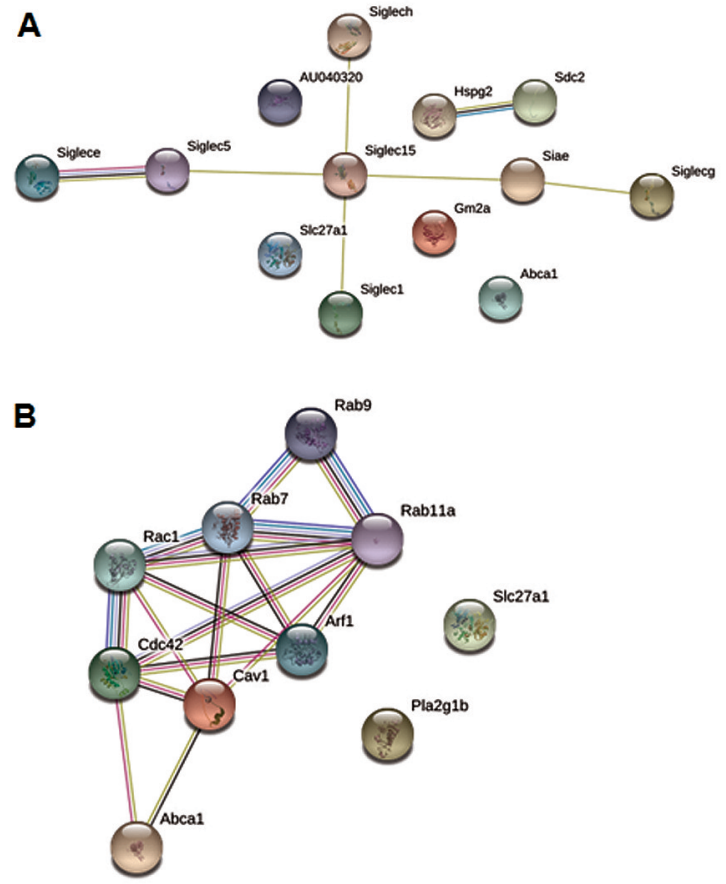

Figure 10. The relationship of proteins between lipid regulated genes and surface receptors of cells for rAAV vectors (10A) and the relationship of proteins involved in intracellular transport of $r A A V(10 B)$. Scheme is made on the basis of STRING program (https://string-db.org/). Network nodes represent proteins: splice isoforms or post-translational modifications are collapsed, i.e. each node represents all the proteins produced by a single, protein-coding gene locus. Node color: colored nodes: query proteins and first shell of interactors. White nodes: second shell of interactions. Empty nodes: proteins of unknown $3 D$ structure. Filed nodes: some $3 D$ structure is known or predicted. Edges represent protein-protein associations: associations are meant to be specific and meaningful, i.e. proteins jointly contribute to a shared function; this does not necessarily mean they are physically binding each other. Known interactions: blue: from curated databases, pink: experimentally determined. Predicted interactions: green: gene neighborhood, red: gene fusions, dark blue: gene co-occurrence. Others: yellow: textmining, black: co-expression, violet: protein homology.

to the lungs (Figures 7A, C and 8). Therefore, this research provides evidence for effective administration of rAAV vectors to metastatic melanoma cells. Thus, gene therapy and rAAV vectors can be a new and effective therapeutic strategy for melanoma and its lung metastases.

\section{Conflicts of Interest}

The Authors have no conflicts of interest to disclose in relation to this study.

\section{Authors' Contributions}

M.M. conceived the presented idea and planned the experiments. Both M.C. and M.M. contributed to the final version of the
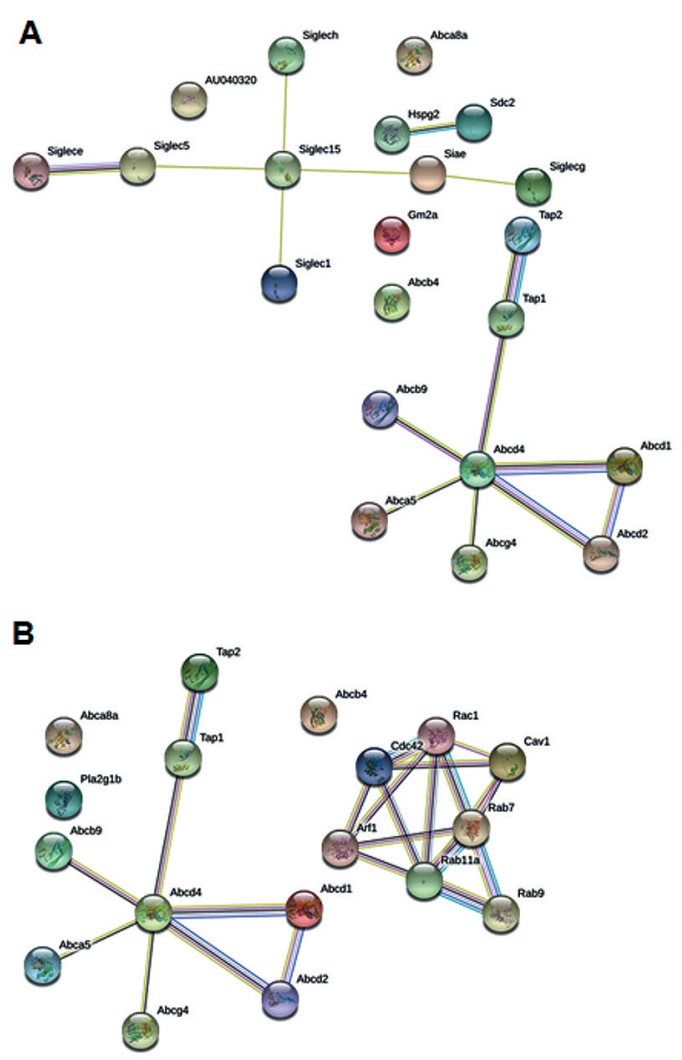

Figure 11. The relationship of proteins between $A B C$ transporters and surface receptors of cells for $r A A V(11 A)$ and the relationship of proteins which are involved in the intracellular transport of $r A A V(11 B)$. Scheme is made on the basis of the STRING program. Network nodes represent proteins: splice isoforms or post-translational modifications are collapsed, i.e. each node represents all the proteins produced by a single, proteincoding gene locus. Node color: colored nodes: query proteins and first shell of interactors. White nodes: second shell of interactions. Empty nodes: proteins of unknown 3D structure. Filed nodes: some $3 D$ structure is known or predicted. Edges represent protein-protein associations: associations are meant to be specific and meaningful, i.e. proteins jointly contribute to a shared function; this does not necessarily mean they are physically binding each other. Known interactions: blue: from curated databases, pink: experimentally determined. Predicted interactions: green: gene neighborhood, red: gene fusions, dark blue: gene co-occurrence. Others: yellow: textmining, black: co-expression, violet: protein homology.

manuscript. M.C. carried out all the experiments. M.C. developed the theoretical formalism, performed the calculations, analysed the data and wrote the paper. A.Z. revised the methods and qPCR results. M.G. helped carry out the immunochemical analysis. M. B-Z. helped in the supervision.

\section{Acknowledgements}

This work was supported by a grant from The National Centre for Research and Development (Strategmed/233264/4/NCBR/2014, MentorEYE). 


\section{References}

1 Leonardi GC, Falzone L, Salemi R, Zanghi A, Spandidos DA, Mccubrey JA, Candido S and Libra M: Cutaneous melanoma: From pathogenesis to therapy (Review). Int J Oncol 52: 10711080, 2018. PMID: 29532857. DOI: 10.3892/ijo.2018.4287

2 Domingues B, Lopes JM, Soares P and Populo H: Melanoma treatment in review. Immunotargets Ther 7: 35-39, 2018. PMID: 29922629. DOI: $10.2147 /$ ITT.S134842

3 Nunes TWN, Filippi-Chiela EC, Callegari-Jacques SM, da Silva VD, Sansonowicz T, Lenz G and Roehe AV: Nuclear morphometric analysis in tissue as an objective tool with potential use to improve melanoma staging. Melanoma Res 29: 474-482, 2019. PMID: 30839356. DOI: 10.1097/CMR.00000000 00000594

4 Hodi FS, O'Day SJ, McDermott DF, Weber RW, Sosman JA, Haanen JB, Gonzalez R, Robert C, Schadendorf D, Hassel JC, Akerley W, van den Eertwegh AJ, Lutzky J, Lorigan P, Vaubel JM, Linette GP, Hogg D, Ottensmeier CH, Lebbé C, Peschel C, Quirt I, Clark JI, Wolchok JD, Weber JS, Tian J, Yellin MJ, Nichol GM, Hoos A and Urba WJ: Improved survival with ipilimumab in patients with metastatic melanoma. N Engl J Med 363: 711-723, 2010. PMID: 20525992. DOI: 10.1056/NEJMoa1003466

5 Kianmehr Z, Khorsandi K, Mohammadi and Hosseinzadeh R: Low-level laser irradiation potentiates anticancer activity of $\mathrm{p}$ coumaric acid against human malignant melanoma cells. Melanoma Res 30: 136-146, 2020. PMID: 30855528. DOI: 10.1097/CMR.0000000000000603

6 Wilson MA, Zhong J, Rosenbaum BE, Utter K, Moran U, Darvishian F, Polsky D, Berman RS, Shapiro RL, Pavlick AC and Osman I: Impact of initial stage on metastatic melanoma survival. Melanoma Res 29: 281-288, 2019. PMID: 31026246. DOI: 10.1097/CMR.0000000000000526

7 Lee JH, Kim Y, Yoon YE, Kim YJ, Oh SG, Jang JH and Kim E: Development of efficient adeno-associated virus (AAV)-mediated gene delivery system with a phytoactive material for targeting human melanoma cells. N Biotechnol 37(Pt B): 194-199, 2017. PMID: 28179151. DOI: 10.1016/j.nbt.2017.02.001

8 Ghazawi FM, Darwich R, Le M, Rahme E, Zubarev A, Moreau L, Burnier JV, Sasseville D, Burnier MN and Litvinov IV: Uveal melanoma incidence trends in Canada: a national comprehensive population-based study. Br J Ophthamol 103: 1872-1876, 2019. PMID: 30819691. DOI: 10.1136/bjophthalmol-2018-312966

9 Donley GM, Liu WT, Pfeiffer RM, McDonald EC, Peters KO, Tucker MA and Cahoon EK: Reproductive factors, exogenous hormone use and incidence of melanoma among women in the United States. Br J Cancer 120: 754-760, 2019. PMID: 30814688. DOI: $10.1038 / \mathrm{s} 41416-019-0411-\mathrm{z}$

10 Flotte TR: Gene Therapy Progress and Prospects: Recombinant adeno-associated virus (rAAV) vectors. Gene Ther 11: 805-810, 2004. PMID: 15042119 . DOI: $10.1038 /$ sj.gt.3302233

11 Wan X, Pei H, Zhao MJ, Yang S, Hu WK, He H, Ma SQ, Zhang G, Dong XY, Chen C, Wang DW and Li B: Efficacy and safety of rAAV2-ND4 treatment for leber's hereditary optic neuropathy. Sci Rep 6: 21587, 2016. PMID: 26892229. DOI: 10.1038/srep21587

12 Corti M, Liberati C, Smith BK, Lawson LA, Tuna IS, Conlon TJ, Coleman KE, Islam S, Herzog RW, Fuller DD, Collins SW and Byrne BJ: Safety of intradiaphragmatic delivery of adenoassociated virus-mediated alpha-glucosidase (rAAV1-CMVhGAA) gene therapy in children affected by pompe disease. Hum
Gene Ther Clin Dev 28: 208-218, 2017. PMID: 29160099. DOI: 10.1089/humc.2017.146

13 European Medicines Agency. Science Medicines Healthy. Available at: www.ema.europa.eu/en/documents/overview/ glybera-epar-summary-public_en.pdfah [Last accessed June 12, 2020]

14 European Medicines Agency. Science Medicines Healthy. Available at: https://www.ema.europa.eu/en/medicines/human/ EPAR/luxturna [Last accessed June 12, 2020]

15 Hashimoto H, Mizushima T, Chijiwa T, Nakamura M and Suemizu H: Efficient production of recombinant adenoassociated viral vector, serotype DJ/8, carrying the GFP gene. Virus Res 238: 63-68, 2017. PMID: 28571759. DOI: 10.1016/j.virusres.2017.05.017

16 Smith JK and Agbandje-McKenna M: Creating an arsenal of Adeno-associated virus (AAV) gene delivery stealth vehicles. PLoS Pathog 14(5): e1006929, 2018. PMID: 29723270. DOI: 10.1371/journal.ppat.1006929

17 Hess GT, Tycko J, Yao D and Bassik MC: Methods and applications of CRISPR-mediated base editing in eukaryotic genomes. Mol Cell 68: 26-43, 2017. PMID: 28985508. DOI: 10.1016/j.molcel.2017.09.029

18 Liu XS, Wu H, Krzisch M, Wu X, Graef J, Muffat J, Hnisz D, Li CH, Yuan B, Xu C, Li Y, Vershkov D, Cacace A, Young RA and Jaenisch R: Rescue of fragile $\mathrm{X}$ syndrome neurons by DNA methylation editing of the FMR1 gene. Cell 172(5): 979-992.e6, 2018. PMID: 29456084. DOI: 10.1016/j.cell.2018.01.012

19 Zimmermann M, Murina O, Reijns MAM, Agathanggelou A, Challis R, Tarnauskaite Ž, Muir M, Fluteau A, Aregger M, McEwan A, Yuan W, Clarke M, Lambros MB, Paneesha S, Moss P, Chandrashekhar M, Angers S, Moffat J, Brunton VG, Hart T, de Bono J, Stankovic T, Jackson AP and Durocher D: CRISPR screens identify genomic ribonucleotides as a source of PARPtrapping lesions. Nature 559(7713): 285-289, 2018. PMID: 29973717. DOI: $10.1038 / \mathrm{s} 41586-018-0291-\mathrm{z}$

20 Sachdeva M, Sachdeva N, Pal M, Gupta N, Khan IA, Majumdar $\mathrm{M}$ and Tiwari A: CRISPR/Cas9: molecular tool for gene therapy to target genome and epigenome in the treatment of lung cancer. Cancer Gene Ther 22: 509-517, 2015. PMID: 26494554. DOI: 10.1038/cgt.2015.54

21 Platt RJ, Chen S, Zhou Y, Yim MJ, Swiech L, Kempton HR, Dahlman JE, Parnas O, Eisenhaure TM, Jovanovic M, Graham DB, Jhunjhunwala S, Heidenreich M, Xavier RJ, Langer R, Anderson DG, Hacohen N, Regev A, Feng G, Sharp PA and Zhang F: CRISPR-Cas9 knockin mice for genome editing and cancer modeling. Cell 159: 440-455, 2014. PMID: 25263330. DOI: 10.1016/j.cell.2014.09.014

22 Ding Q, Strong A, Pate KM, Ng SL, Gosis BS, Regan SN, Cowan CA, Rader DJ and Musunuru K: Permanent alteration of PCSK9 with in vivo CRISPR-Cas9 genome editing. Circ Res 115: 488-492, 2014. PMID: 24916110. DOI: 10.1161/CIRCRES AHA.115.304351

23 Rossidis AC, Stratigis JD, Chadwick AC, Hartman HA, Ahn NJ, Li H, Singh K, Coons BE, Li L, Lv W, Zoltick PW, Alapati D, Zacharias W, Jain R, Morrisey EE, Musunuru K and Peranteau WH: In utero CRISPR-mediated therapeutic editing of metabolic genes. Nat Med 24(10): 1513-1518, 2018. PMID: 30297903. DOI: 10.1038/s41591-018-0184-6

24 Ou Z, Niu X, He W, Chen Y, Song B, Xian Y, Fan D, Tang D and Sun X: The combination of CRISPR/Cas9 and iPSC technologies 
in the gene therapy of human beta-thalassemia in mice. Sci Rep 6: 32463, 2016. PMID: 27581487. DOI: 10.1038/srep32463

25 Long C, Amoasii L, Mireault AA, McAnally JR, Li H, SanchezOrtiz E, Bhattacharyya S, Shelton JM, Bassel-Duby R and Olson EN: Postnatal genome editing partially restores dystrophin expression in a mouse model of muscular dystrophy. Science 351(6271): 400-403, 2016. PMID: 26721683. DOI: 10.1126/ science.aad5725

26 Nelson CE, Hakim CH, Ousterout DG, Thakore PI, Moreb EA, Castellanos Rivera RM, Madhavan S, Pan X, Ran FA, Yan WX, Asokan A, Zhang F, Duan D and Gersbach CA: In vivo genome editing improves muscle function in a mouse model of Duchenne muscular dystrophy. Science 351(6271): 403-407, 2016. PMID: 26721684. DOI: $10.1126 /$ science.aad5143

27 Tabebordbar M, Zhu K, Cheng JKW, Chew WL, Widrick JJ, Yan WX, Maesner C, Wu EY, Xiao R, Ran FA, Cong L, Zhang F, Vandenberghe LH, Church GM and Wagers AJ: In vivo gene editing in dystrophic mouse muscle and muscle stem cells. Science 351(6271): 407-411, 2016. PMID: 26721686. DOI: 10.1126/science.aad5177

28 Ma H, Marti-Gutierrez N, Park SW, Wu J, Lee Y, Suzuki K, Koski A, Ji D, Hayama T, Ahmed R, Darby H, Van Dyken C, Li Y, Kang E, Park AR, Kim D, Kim ST, Gong J, Gu Y, Xu X, Battaglia D, Krieg SA, Lee DM, Wu DH, Wolf DP, Heitner SB, Belmonte JCI, Amato P, Kim JS, Kaul S and Mitalipov S: Correction of a pathogenic gene mutation in human embryos. Nature 548(7668): 413-441, 2017. PMID: 28783728. DOI: 10.1038/nature23305

29 Kim K, Ryu SM, Kim ST, Baek G, Kim D, Lim K, Chung E, Kim S and Kim JS: Highly efficient RNA-guided base editing in mouse embryos. Nat Biotechnol 35(5): 435-437, 2017. PMID: 28244995. DOI: $10.1038 /$ nbt.3816

30 Yu W, Mookherjee S, Chaitankar V, Hiriyanna S, Kim JW, Brooks M, Ataeijannati Y, Sun X, Dong L, Li T, Swaroop A and Wu Z: Nrl knockdown by AAV-delivered CRISPR/Cas9 prevents retinal degeneration in mice. Nat Commun 8: 14716, 2017. PMID: 28291770. DOI: 10.1038/ncomms 14716

31 Amoasii L, Hildyard JCW, Li H, Sanchez-Ortiz E, Mireault A, Caballero D, Harron R, Stathopoulou TR, Massey C, Shelton JM, Bassel-Duby R, Piercy RJ and Olson EN: Gene editing restores dystrophin expression in a canine model of Duchenne muscular dystrophy. Science 362(6410): 86-91, 2018. PMID: 30166439. DOI: $10.1126 /$ science.aau 1549

32 Villiger L, Grisch-Chan HM, Lindsay H, Ringnalda F, Pogliano CB, Allegri G, Fingerhut R, Häberle J, Matos J, Robinson MD, Thöny B and Schwank G: Treatment of a metabolic liver disease by in vivo genome base editing in adult mice. Nat Med 24(10): 1519-1525, 2018. PMID: 30297904. DOI: 10.1038/s41591-0180209-1

33 Choi VW, McCarty DM and Samulski RJ: AAV hybrid serotypes: improved vectors for gene delivery. Curr Gene Ther 5(3): 299-310, 2005. PMID: 15975007. DOI: 10.2174/ 1566523054064968

34 Grimm D, Lee JS, Wang L, Desai T, Akache B, Storm TA and Kay MA: In vitro and in vivo gene therapy vector evolution via multispecies interbreeding and retargeting of adeno-associated viruses. J Virol 82(12): 5887-5911, 2008. PMID: 18400866. DOI: 10.1128/JVI.00254-08

35 Katada Y, Kobayashi K, Tsubota K and Kurihara T: Evaluation of AAV-DJ vector for retinal gene therapy. PeerJ 7: e6317, 2019. PMID: 30671314. DOI: 10.7717/peerj.6317
36 Mao Y, Wang X, Yan R, Hu W, Li A, Wang S and Li H: Single point mutation in adeno-associated viral vectors -DJ capsid leads to improvement for gene delivery in vivo. BMC Biotechnol 16: 1, 2016. PMID: 26729248. DOI: 10.1186/s12896-015-0230-0

37 Santiago-Ortiz JL and David V. Schaffer DV: Adeno-associated virus (AAV) vectors in cancer gene therapy. J Control Release 240: 287-301, 2016. PMID: 26796040. DOI: 10.1016/j.jconrel. 2016.01.001

38 Bienkowska A, Kuzmicka W, Ciepiela O, Ochocki J and Malecki M: Increased temperature facilitates adeno-associated virus vector transduction of colorectal cancer cell lines in a manner dependent on heat shock protein signature. Biomed Res Int 8: 2020,9107140, 2020. PMID: 32090115. DOI: $10.1155 / 2020 / 9107140$

39 Podolska K, Stachurska A, Hajdukiewicz K and Malecki M. Gene therapy prospects - intranasal delivery of therapeutic genes. Adv Clin Exp Med 21(4): 525-34, 2012. PMID: 23240459.

40 Santry LA, Ingrao JC, Yu DL, de Jong JG, van Lieshout LP, Wood GA and Wootton SK: AAV vector distribution in the mouse respiratory tract following four different methods of administration. BMC Biotechnol 17(1): 43, 2017. PMID: 28506256. DOI: 10.1186/s 12896-017-0365-2

41 Nass SA, Mattingly MA, Woodcock DA, Burnham BL, Ardinger JA, Osmond SE, Frederick AM, Scaria A, Cheng SH and O'Riordan CR: Universal method for the purification of recombinant AAV vectors of differing serotypes. Mol Ther Methods Clin Dev 9: 33-46, 2017. PMID: 29349097. DOI: 10.1016/j.omtm.2017.12.004

42 Uytingco CR and Martens JR: Intranasal delivery of adenoviral and AAV vectors for transduction of the mammalian peripheral olfactory system. Methods Mol Biol 1950: 283-297, 2019. PMID: 30783981. DOI: 10.1007/978-1-4939-9139-6_17

43 Marchenko I, Borodina T, Trushina D, Rassokhina I, Volkova Y, Shirinian V, Zavarzin I, Gogin A and Bukreeva T: Mesoporous particle-based microcontainers for intranasal delivery of imidazopyridine drugs. J Microencapsul 35(7-8): 657-666, 2018. PMID: 30669903. DOI: 10.1080/02652048.2019.1571642

44 Wingrove J, Swedrowska M, Scherließ R, Parry M, Ramjeeawon M, Taylor D, Gauthier G, Brown L, Amiel S, Zelaya F and Forbes B: Characterisation of nasal devices for delivery of insulin to the brain and evaluation in humans using functional magnetic resonance imaging. J Control Release 302: 140-114, 2019. PMID: 30953665. DOI: 10.1016/j.jconrel.2019.03.032

45 Costa C, Moreira JN, Amaral MH, Sousa Lobo JM and Silva AC: Nose-to-brain delivery of lipid-based nanosystems for epileptic seizures and anxiety crisis. J Control Release 295: 187-200, 2019. PMID: 30610952. DOI: 10.1016/j.jconrel.2018.12.049

46 Mastrandrea LD and Quattrin T: Clinical evaluation of inhaled insulin. Adv Drug Deliv Rev 58(9-10): 1061-1075, 2006. PMID: 17070613. DOI: 10.1016/j.addr.2006.07.019

47 Guntur VP and Dhand R: Inhaled insulin: extending the horizons of inhalation therapy. Respir Care 52(7): 911-922, 2007. PMID: 17594734 .

48 Codrons V, Vanderbist F and Verbeeck RK: Systemic delivery of parathyroid hormone (1-34) using inhalation dry powders in rats. J Pharm Sci 92(5): 938-50, 2003. PMID: 12712413. DOI: $10.1002 /$ jps. 10346

49 Gessler T, Seeger W and Schmehl T: Inhaled prostanoids in the therapy of pulmonaryhypertension. J Aerosol Med 21(1): 1-12, 2008. PMID: 18518827. DOI: 10.1089/jamp.2007.0657 
50 Mikhail N: Place of technosphere inhaled insulin in treatment of diabetes. World J Diabetes 7(20): 599-604, 2016. PMID: 28031777. DOI: $10.4239 /$ wjd.v7.i20.599

51 Ahmad Z, Sharma S and Khuller GK: Inhaleable alginate nanoparticles as antitubercular drug carriers against experimental tuberculosis. Int J Antimicrob Agents 26(4): 298-303, 2005. PMID: 16154726. DOI: 10.1016/j.ijantimicag.2005.07.012

52 Justo OR and Moraes AM: Kanamycin incorporation in lipid vesicles prepared by ethanol injection designed for tuberculosis treatment. Pharm Pharmacol 57(1): 23-30, 2005. PMID: 15638989. DOI: $10.1211 / 0022357055092$

53 Garcia-Contreras L, Marcol T, Bell SJD and Hickey AJ: Evaluation of novel particles as pulmonary delivery systems for insulin in rats. AAPS Pharm Sci 5(2): 9, 2003. PMID: 12866936. DOI: $10.1208 / \mathrm{ps} 050209$

54 Davies NM and Feddah MR: A novel method for assessing dissolution of aerosol inhaler products. Int J Pharm 255: 175-187, 2003. PMID: 12672613. DOI: 10.1016/s0378-5173(03)00091-7

55 Djupesland PG: Nasal drug delivery devices: characteristics and performance in a clinical perspective - a review. Drug Deliv Transl Res 3(1): 42-62, 2013. PMID: 23316447. DOI: 10.1007/ s13346-012-0108-9

56 Johansson J, Hirvonen J, Lovró Z, Ekblad L, Kaasinen V, Rajasilta O, Helin S, Tuisku J, Sirén S, Pennanen M, Agrawal A, Crystal R, Vainio PJ, Alho $\mathrm{H}$ and Scheinin M: Intranasal naloxone rapidly occupies brain mu-opioid receptors in human subjects. Neuropsychopharmacology 44(9): 1667-1673, 2019. PMID: 30867551. DOI: 10.1038/s41386-019-0368-x

57 Santiago JCP and Hallschmid M: Outcomes and clinical implications of intranasal insulin administration to the central nervous system. Exp Neurol 317: 180-190, 2019. PMID: 30885653. DOI: 10.1016/j.expneurol.2019.03.007

58 Mustapic M, Tran J, Craft S and Kapogiannis D: Extracellular vesicle biomarkers track cognitive changes following intranasal insulin in Alzheimer's disease. J Alzheimers Dis 69(2): 489-498, 2019. PMID: 30958348. DOI: 10.3233/JAD-180578

59 Tao Y, Li C, Yao A, Qu Y, Qin L, Xiong Z, Zhang J and Wang $\mathrm{W}$ : Intranasal administration of erythropoietin rescues the photoreceptors in degenerative retina: a noninvasive method to deliver drugs to the eye. Drug Deliv 26(1): 78-88, 2019. PMID: 30744451. DOI: 10.1080/10717544.2018.1556361

60 Vandenbussche $\mathrm{N}$ and Goadsby PJ: The discovery and development of inhaled therapeutics for migraine. Expert Opin Drug Discov 14(6): 591-599, 2019. PMID: 30924698. DOI: 10.1080/17460441.2019.1598373

61 Musumeci T, Bonaccorso A and Puglisi G: Epilepsy disease and nose-to-brain delivery of polymeric nanoparticles: an overview. Pharmaceutics 11(3): pii: E118, 2019. PMID: 30871237. DOI: 10.3390/pharmaceutics11030118

62 Ma X-c, Liu P, Zhang X-1, Jiang WH, Jia M, Wang CX, Dong YY, Dang YH and Gao CG: Intranasal delivery of recombinant AAV containing BDNF fused with ha2tat: a potential promising therapy strategy for major depressive disorder. Sci Rep 6: 22404, 2016. PMID: 26935651. DOI: 10.1038/srep22404

63 Jiao J and Zhang L: Influence of intranasal drugs on human nasal mucociliary clearance and ciliary beat frequency. Allergy Asthma Immunol Res 11(3): 306-319, 2019. PMID: 30912321. DOI: 10.4168/aair.2019.11.3.306

64 Belur LR, Temme A, Podetz-Pedersen KM, Riedl M, Vulchanova L, Robinson N, Hanson LR, Kozarsky KF, Orchard
PJ, Frey WH 2nd, Low WC and McIvor RS: Intranasal adenoassociated virus mediated gene delivery and expression of human iduronidase in the central nervous system: A noninvasive and effective approach for prevention of neurologic disease in mucopolysaccharidosis type I. Hum Gene Ther 28(7): 576-587, 2017. PMID: 28462595. DOI: 10.1089/hum.2017.187

65 Werling NJ, Satkunanathan S, Thorpe R and Zhao Y: Systematic comparison and validation of quantitative real-time PCR methods for the quantitation of adeno-associated viral products. Hum Gene Ther Method 26(3): 82-92, 2015. PMID: 25953194. DOI: 10.1089/hgtb.2015.013

66 Schindelin J, Arganda-Carreras I, Frise E, Kaynig V, Longair M, Pietzsch T, Preibisch S, Rueden C, Saalfeld S, Schmid B, Tinevez JY, White DJ, Hartenstein V, Eliceiri K, Tomancak P and Cardona A: Fiji: an open-source platform for biological-image analysis. Nat Methods 9(7): 676-682, 2012. PMID: 22743772. DOI: 10.1038/nmeth.2019

67 Matthews NH, Li WQ, Qureshi, Martin A. Weinstock and Eunyoung Cho: Chapter 1. Epidemiology of melanoma. cutaneous melanoma: etiology and therapy. Ward WH, Farma JM (eds.). Brisbane (AU): Codon Publications Pages pp. 3-22, 2017. PMID: 29461771. DOI: 10.15586/codon.cutaneousmelanoma.2017

68 Velu PP, Cao Ch and Yan TD: Current surgical management of melanoma metastases to the lung. J Thorac Dis (Suppl 3): S274S276, 2013. PMID: 24040536. DOI: 10.3978/j.issn.20721439.2013.08.42

69 Paolino G, Bottoni U, Clerico R, Didona D, Venuta F, Corsett P, Ambrifi M, Cantisani C, Richetta GA, Lopez T and Calvieri S: Clinicopathological predictive factors of melanoma lung metastases. J Integr Oncol 3: 119, 2014. DOI: 10.4172/23296771.1000119

70 Limberis MP, Vandenberghe LH, Zhang L, Pickles RJ and Wilson JM: Transduction efficiencies of novel RAAV vectors in mouse airway epithelium in vivo and human ciliated airway epithelium in vitro. Mol Ther 17(2): 294-301, 2009. PMID: 19066597. DOI: $10.1038 / \mathrm{mt} .2008 .261$

71 Damjanovic D, Zhang X, Mu J, Medina MF and Xing Z: Organ distribution of transgene expression following intranasal mucosal delivery of recombinant replication-defective adenovirus gene transfer vector. Gen Vaccines Ther 6: 5, 2008. PMID: 18261231 DOI: $10.1186 / 1479-0556-6-5$

72 van Lieshout LP, Domm JM and Wootton SK: AAV-mediated gene delivery to the lung. Methods Mol Biol 1950: 361-372, 2019. PMID: 30783985. DOI: 10.1007/978-1-4939-9139-6_21

73 Katz MG, Fargnoli AS, Gubara SM, Fish K, Weber T, Bridges CR, Hajjar RJ and Ishikawa K: Targeted gene delivery through the respiratory system: rationale for intratracheal gene transfer. J Cardiovasc Dev Dis 6(1): 8, 2019. PMID: 30781363. DOI: $10.3390 /$ jcdd 6010008

74 The Journal of Gene Medicine Clinical Trial site. Available at: http://www.abedia.com/wiley/index.html [Last Accessed June 20, 2016]

75 Czajka M, Zajkowska A, Stachowiak N and Malecki M: Cancer gene therapy: The estimation of reporter genes delivery to B16F10 melanoma cells. J Eur Acad Dermatol Venerol 31: 67, 2017.

76 Zajkowska A, Czajka M, Slyk Z and Malecki M: MicroRNA signature of the B16-F10 melanoma cells infected with adenoassociated viral vectors. J Stem Cell Res Ther, 2016. DOI: 10.4172/2157-7633.C1.024 
77 Al-Dosari MS and Gao X: Nonviral gene delivery: principle, limitations, and recent progress. AAPS J 11(4): 671-681, 2009. PMID: 19834816. DOI: 10.1208/s12248-009-9143-y

78 Tsoukalas C, Geninatti-Crich S, Gaitanis A, Tsotakos T, ParavatouPetsotas M, Aime S, Jiménez-Juárez R, Anagnostopoulos CD, Djanashvili $\mathrm{K}$ and Bouziotis P: Tumor targeting via sialic acid: [68Ga]DOTA-en-pba as a new tool for molecular imaging of cancer with PET. Mol Imaging Biol 20(5): 798-807, 2018. PMID: 29464496. DOI: 10.1007/s11307-018-1176-0

79 Engbring JA, Hoffman MP, Karmand AJ and Kleinman HK: The B16F10 cell receptor for a metastasis-promoting site on laminin1 is a heparan sulfate/chondroitin sulfate-containing proteoglycan. Cancer Res 62(12): 3549-3554, 2002. PMID: 12068003.

80 Raz A, McLellan WL, Hart IR, Bucana Cd, Hoyer LC, Sela BA, Dragsten $\mathrm{P}$ and Fidler IJ: Cell surface properties of B16 melanoma variants with differing metastatic potential. Cancer Res 40(5): 1645-1651, 1980. PMID: 7370996.

81 Metzner T, Bedeir A, Held G, Peter-Vörösmarty B, Ghassemi S, Heinzle C, Spiegl-Kreinecker S, Marian B, Holzmann K, GraslKraupp B, Pirker C, Micksche M, Berger W, Heffeter P and Grusch M: Fibroblast growth factor receptors as therapeutic targets in human melanoma: synergism with BRAF inhibition. J Invest Dermatol 131(10): 2087-2095, 2011. PMID: 21753785. DOI: $10.1038 /$ jid.2011.177

82 Gitay-Goren H, Halaban R and Neufeld G: Human melanoma cells but not normal melanocytes express vascular endothelial growth factor receptor. Biochem Biophys Res Commun 190(3): 702-708, 1993. PMID: 8439321. DOI: 10.1006/bbrc.1993.1106

83 Felding-Habermann B, Mueller BM, Romerdahl CA and Cheresh DA: Involvement of integrin alpha $\mathrm{V}$ gene expression in human melanoma tumorigenicity. J Clin Invest 89(6): 2018-2022, 1992. PMID: 1376331. DOI: 10.1172/JCI115811

84 Schmidt $M$ and Chiorini JA: Gangliosides are essential for bovine adeno-associated virus entry. J Virol 80(11): 5516-5522, 2006. PMID: 16699032. DOI: 10.1128/JVI.02393-05

85 Fishman PH, Brady RO, Bradley RM, Aaronson SA and Tadaro GJ: Absence of a specific ganglioside galactosyltransferase in mouse cells transformed by murine sarcoma virus. Proc Natl Acad Sci USA 71(2): 298-301, 1974. PMID: 4360937. DOI: 10.1073/pnas.71.2.298

86 Opie SR, Warrington KH Jr, Agbandje-McKenna M, Zolotukhin $\mathrm{S}$ and Muzyczka N: Identification of amino acid residues in the capsid proteins of adeno-associated virus type 2 that contribute to heparan sulfate proteoglycan binding. J Virol 77(12): 69957006, 2003. PMID: 12768018. DOI: 10.1128/jvi.77.12.69957006.2003

87 Weber M, Rabinowitz J, Provost N, Conrath H, Folliot S, Briot D, Chérel Y, Chenuaud P, Samulski J, Moullier P and Rolling F: Recombinant adeno-associated virus serotype 4 mediates unique and exclusive long-term transduction of retinal pigmented epithelium in rat, dog, and nonhuman primate after subretinal delivery. Mol Ther 7(6): 774-781, 2003. PMID: 12788651. DOI: 10.1016/s1525-0016(03)00098-4

88 Walters RW, Yi SM, Keshavjee S, Brown KE, Welsh MJ, Chiorini JA and Zabner J: Binding of adeno-associated virus type 5 to 2,3-linked sialic acid is required for gene transfer. J Biol Chem 276(23): 20610-2061, 2001. PMID: 11262413. DOI: 10.1074/jbc.M101559200

89 Arbetman AE, Lochrie M, Zhou S, Wellman J, Scallan C, Doroudchi MM, Randlev V, Patarroyo-White S, Liu T, Smith P,
Lehmkuhi H, Hobbs LA, Pierce GF and Colosi P: Novel caprine adeno-associated virus (RAAV) capsid (RAAV-Go.1) is closely related to the primate RAAV-5 and has unique tropism and neutralization properties. J Virol 79(24): 15238-15245, 2005. PMID: 16306595. DOI: 10.1128/JVI.79.24.15238-15245.2005

90 Naso MF, Tomkowicz B, Perry WL and Strohl WR: Adenoassociated virus (RAAV) as a vector for gene therapy. BioDrugs 31(4): 317-334, 2017. PMID: 28669112. DOI: 10.1007/s40259017-0234-5

91 Kurosaki F, Uchibori R, Mato N, Sehera Y, Saga Y, Urabe M, Mizukami H, Sugiyama Y and Kume A: Optimization of adenoassociated virus vector-mediated gene transfer to the respiratory tract. Gene Ther 24(5): 290-297, 2017. PMID: 28346434. DOI: $10.1038 /$ gt.2017.19

92 Damdindorj L, Karnan S, Ota A, Hossain E, Konishi Y, Hosokawa $\mathrm{Y}$ and Konishi H: A comparative analysis of constitutive promoters located in adeno-associated viral vectors. PLoS One 9(8): e106472. 32, 2014. PMID: 25170953. DOI: 10.1371/journal.pone.0106472

93 Gray SJ, Foti SB, Schwartz JW, Bachaboina L, Taylor-Blake T, Coleman J, Ehlers MD, Zylka MJ, McCrown TJ and Samulski RJ: Optimizing promoters for recombinant adeno-associated virus-mediated gene expression in the peripheral and central nervous system using self-complementary vectors. Hum Gene Ther 22(9): 1143-1153, 2011. PMID: 21476867. DOI: 10.1089/hum.2010.245

94 Alton EW, Beekman JM, Boyd AC, Brand J, Carlon MS, Connolly MM, Chan M, Conlon S, Davidson HE, Davies JC, Davies LA, Dekkers JF, Doherty A, Gea-Sorli S, Gill DR, Griesenbach U, Hasegawa M, Higgins TE, Hironaka T, Hyndman L, McLachlan G, Inoue M, Hyde SC, Innes JA, Maher TM, Moran C, Meng C, Paul-Smith MC, Pringle IA, Pytel KM, Rodriguez-Martinez A, Schmidt AC, Stevenson BJ, SumnerJones SG, Toshner R, Tsugumine S, Wasowicz MW and Zhu J: Preparation for a first-in-man lentivirus trial in patients with cystic fibrosis. Thorax 72(2): 137-147, 2017. PMID: 27852956. DOI: 10.1136/thoraxjnl-2016-208406

95 Nonnenmacher $\mathrm{M}$ and Weber $\mathrm{T}$ : Adeno-associated virus 2 infection requires endocytosis through the CLIC/GEEC pathway. Cell Host Microbe 10(6): 563-76, 2011. PMID: 22177561. DOI: 10.1016/j.chom.2011.10.014

96 Zhang Y, Lu J, Ma j and Liu X: Insulin-induced gene 1 (INSIG1) inhibitis HIV-1 production by degrading Gag via activity of the ubiquitin ligase TRC8. J Biol Chem 294(6): 2046-2059, 2019. PMID: 30563842. DOI: 10.1074/jbc.RA118.004630

97 Liu C, Liu Y, Liang L, Cui S and Zhang Y: RNA-Seq based transcriptome analysis during bovine viral diarrhea virus (BVDV) infection. BMC Genomics 20(1): 774, 2019. PMID: 31651237. DOI: $10.1186 / \mathrm{s} 12864-019-6120-4$

98 Siddigui R, Suzu S, Ueno M, Nasser H, Koba R, Bhuyan F, Noyori O, Hamidi S, Sheng G, Yasuda-Inoue M, Hishiki T, Sukegawa S, Miyagi E, Strebel K, Matsushita S, Shimotohno K and Ariumi Y: Apolipoprotein $\mathrm{E}$ is an HIV-1-inducible inhibitor of viral production and infectivity in macrophages. PLoS Pathog 14(11): e1007372, 2018. PMID: 30496280. DOI: 10.1371/journal.ppat.1007372

99 Qiao L and Luo GG: Human apolipoprotein E promotes hepatitis B virus infection and production. PLoS Pathog 15(8): e1007874, 2019. PMID: 31393946. DOI: 10.1371/journal.ppat.1007874

100 Kivela AM, Huusko J, Gurzeler E, Laine A, Dijkstra MH, Dragneva G, Andersen CB, Moestrup SK and Ylä-Herttuala S: High plasma lipid levels reduce efficacy of adenovirus-mediated 
gene therapy. Sci Rep 7(1): 386, 2017. PMID: 28341860. DOI: 10.1038/s41598-017-00376-5

101 Lefèvre M, Felmlee DJ, Parnot M, Baumert TF and Schuster C: Syndecan 4 is involved in mediating $\mathrm{HCV}$ entry through interaction with lipoviral particle-associated apolipoprotein E. PLoS One 9(4): e95550, 2014. PMID: 24751902. DOI: 10.1371/ journal.pone.0095550

102 Long J, Roy RB, Zhang YJ, Antrobus R, Du Y, Smith DL, Weekes MP and Javid B: Plasma membrane profiling reveals upregulation of ABCA1 by infected macrophages leading to restriction of mycobacterial growth. Front Microbiol 7: 1086, 2016. PMID: 27462310. DOI: 10.3389/fmicb.2016.01086

103 Arnold N, Girke T, Sureshchandra S and Messaoudi I: Acute simian varicella virus infection causes robust and sustained changes in gene expression in the sensory ganglia. J Virol 90(23): 10823-10843, 2016. PMID: 27681124. DOI: 10.1128/JVI.0127216

104 Aqil M, Mallik S, Bondyopadhyay S, Maulik U and Jameel S: Transcriptomic analysis of mRNAs in human monocytic cells expressing the HIV-1 Nef Protein and their exosomes. Biomed Res Int 2015: 492395, 2015. PMID: 25961023. DOI: 10.1155/ 2015/492395
105 Lerch TF, O’Donnell JK, Mayer NL, Xie Q, Taylor KA, Stagg SM and Chapman MS: Structure of RAAV-DJ, a retargeted gene therapy vector: cryo-electron microscopy at $4.5 \AA$ resolution. Structure 20(8): 1310-1320, 2012. PMID: 22727812. DOI: 10.1016/j.str.2012.05.004

106 van Lieshout LP, Domm JM, Rindler TN, Frost KL, Sorensen DL, Medina SJ, Booth SA, Bridges JP and Wootton SK: A novel triple-mutant RAAV6 capsid induces rapid and potent transgene expression in the muscle and respiratory tract of mice. Mol Ther Methods Clin Dev 9: 323-329, 2018. PMID: 30038936. DOI: 10.1016/j.omtm.2018.04.005
Received May 4, 2020

Revised June 12, 2020

Accepted June 24, 2020 